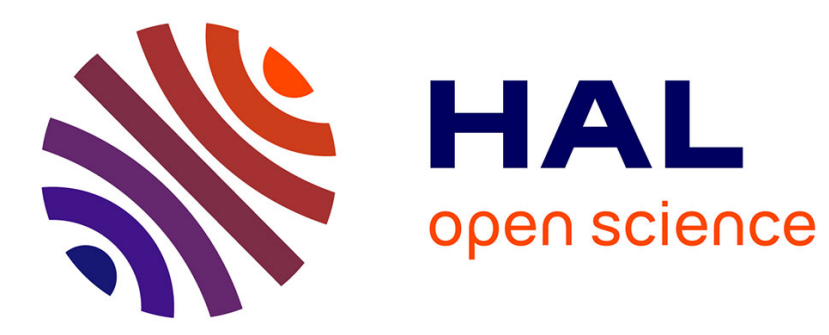

\title{
A study of chromite carbochlorination kinetics
}

\author{
Ndue Kanari, I. Gaballah, Eric Allain
}

\section{To cite this version:}

Ndue Kanari, I. Gaballah, Eric Allain. A study of chromite carbochlorination kinetics. Metallurgical and Materials Transactions B, 1999, 30 (4), pp. 577-587. 10.1007/s11663-999-0018-5 . hal-01508076

\section{HAL Id: hal-01508076 \\ https://hal.univ-lorraine.fr/hal-01508076}

Submitted on 25 May 2017

HAL is a multi-disciplinary open access archive for the deposit and dissemination of scientific research documents, whether they are published or not. The documents may come from teaching and research institutions in France or abroad, or from public or private research centers.
L'archive ouverte pluridisciplinaire HAL, est destinée au dépôt et à la diffusion de documents scientifiques de niveau recherche, publiés ou non, émanant des établissements d'enseignement et de recherche français ou étrangers, des laboratoires publics ou privés. 


\title{
First Version
}

\section{A Study of the Chromite Carbochlorination Kinetics}

\author{
N. KANARI, E. ALLAIN*, and I. GABALLAH \\ Mineral Processing and Environmental Engineering team, \\ LEM $^{\mathrm{a}}, \mathrm{CNRS}^{\mathrm{b}} \mathrm{UMR}^{7569}, \mathrm{ENSG}^{\mathrm{c}}$, INPL $^{\mathrm{d}}$, BP 40, 54501 Vandœuvre, France \\ * University of Missouri-Rolla, School of Mines and Metallurgy, Center for Pyrometallurgy \\ 210 Fulton Hall, 65401 Rolla, MO, USA
}

The carbochlorination of a chromite concentrate was studied between $500{ }^{\circ} \mathrm{C}$ and $1000{ }^{\circ} \mathrm{C}$ using boat experiments. The reaction products were analyzed by SEM, XRD and chemical analysis. The carbochlorination of a chromite concentrate at about $600{ }^{\circ} \mathrm{C}$ led to the partial selective elimination of iron thus increasing the $\mathrm{Cr} / \mathrm{Fe}$ ratio in the treated concentrate. Total carbochlorination of the chromite concentrates and volatilization of the reaction products was achieved at temperatures higher than $800^{\circ} \mathrm{C}$.

Kinetics of the chromite carbochlorination was studied between $750{ }^{\circ} \mathrm{C}$ and $1050{ }^{\circ} \mathrm{C}$ using thermogravimetric analysis. The results were discussed in terms of the effects of gas flow rate, temperature, partial pressure of $\mathrm{Cl}_{2}+\mathrm{CO}$ and $\mathrm{Cl}_{2} / \mathrm{CO}$ ratio on the carbochlorination process. It was observed that the temperature effect changed significantly with the progress of the reaction. The initial stage of the carbochlorination was characterized by apparent activation energy of about 135 and $74 \mathrm{~kJ} / \mathrm{mol}$ below and above $925{ }^{\circ} \mathrm{C}$, respectively. While a value of about of $195 \mathrm{~kJ} / \mathrm{mol}$ was found for the remaining of the carbochlorination process.

\footnotetext{
a. Laboratoire Environnement et Minéralurgie, rue du Doyen M. Roubault, BP 40, 54501 Vandœuvre Cedex, France.

b. Centre National de la Recherche Scientifique, 3 rue MichelAnge, 75794 Paris Cedex, France.

c. École Nationale Supérieure de Géologie, rue du Doyen M. Roubault, BP 40, 54501 Vandœuvre Cedex, France.

d. Institut National Polytechnique de Lorraine, 2 rue de la Forêt de Haye, 54501 Vandœuvre Cedex, France.
} 


\section{INTRODUCTION}

Although the chromium is found in a variety of minerals ${ }^{[1]}$ (crocoïte $\mathrm{PbCrO}_{4}$, vauquelinite $\mathrm{Pb}_{2} \mathrm{Cu}\left[\mathrm{CrO}_{4}\right]\left[\mathrm{PO}_{4}\right]$, uvarovite $\mathrm{Ca}_{3} \mathrm{Cr}_{2}\left[\mathrm{SiO}_{4}\right]_{3}$, merumite $4\left(\mathrm{Cr}, \mathrm{Al}_{2} \mathrm{O}_{3} 3 \mathrm{H}_{2} \mathrm{O}\right.$, etc.), the main ore of chromium is the chromite mineral that is a spinel with the simple formula $\mathrm{FeCr}_{2} \mathrm{O}_{4}$. Chromite belongs to the spinel group and its space group is $\mathrm{Fd} 3 \mathrm{~m}^{[2]}$. However, naturally occurred chromite ore is characterized by the substitution of $\mathrm{Fe}^{2+}$ by $\mathrm{Mg}^{2+}$ and that of $\mathrm{Cr}^{3+}$ by $\mathrm{Al}^{3+}$ and $\mathrm{Fe}^{3+}$ with the following general formula $\left(\mathrm{Mg}, \mathrm{Fe}^{2+}\right)(\mathrm{Cr}, \mathrm{Al}, \mathrm{Fe})^{3+}{ }_{2} \mathrm{O}_{4}$. Figure I shows the chromite structure where the iron and magnesium occupy the tetrahedral sites while the chromium, aluminum, and iron fill the octahedral ones ${ }^{[3]}$. The gangue is essentially composed of orthopyroxene, olivine and plagioclase, as well as hydrous alteration products such as serpentine, chlorite and talc.

About 75 pct of chromite are used for the ferro-chromium production. Moreover, chromite is used for chemical, refractory and foundry applications. Natural characteristics such as the chromium to iron ratio, the chromite grain size and the $\mathrm{SiO}_{2}, \mathrm{Al}_{2} \mathrm{O}_{3}, \mathrm{MgO}$, and $\mathrm{P}$ contents can be as important as the $\mathrm{Cr}_{2} \mathrm{O}_{3}$ content in determining the suitability of a chromite product for various end uses as well as its market price. Table $\mathrm{I}^{[4]}$ represents some chromite specifications for different uses. Thus, the metallurgical chromite is characterized by its high chromium content and a $\mathrm{Cr} / \mathrm{Fe}$ ratio higher than 2 . Conventional mineral processing cannot modify the composition of chromite. This composition can be modified only by using chemical or thermal methods. Chlorination appeared to be a potential approach for beneficiation of poor chromite concentrates and/or ores ${ }^{[5-8]}$. This paper deals with the carbochlorination of chromite concentrate to increase its $\mathrm{Cr} / \mathrm{Fe}$ ratio through selective chlorination of iron compounds. The effect of several parameters on the reaction of chromite mineral with $\mathrm{Cl}_{2}+\mathrm{CO}$ was studied by using thermogravimetric measurements.

The literature is rich with respect to the thermodynamic and kinetic aspects of chlorination of simple oxides contained in the chromite $\left(\mathrm{FeO}, \mathrm{Fe}_{2} \mathrm{O}_{3}, \mathrm{Cr}_{2} \mathrm{O}_{3}, \mathrm{MgO}, \mathrm{Al}_{2} \mathrm{O}_{3}\right.$, and $\left.\mathrm{SiO}_{2}\right)$ using different chlorinating agents. Results of this bibliographic study were summarized in Reference [5] through [8]. However, few publications were devoted to the chlorination of chromite ores and concentrates.

Athawale and Altekar[9] investigated the selective chlorination of iron oxides contained in a chromite concentrate, by using $\mathrm{HCl}$ in a fluidized bed. The authors suggested that the selective chlorination could be carried out effectively between $900{ }^{\circ} \mathrm{C}$ and $950{ }^{\circ} \mathrm{C}$ producing a residue having high $\mathrm{Cr} / \mathrm{Fe}$ ratio useful for the steel industry.

Table I. Chromite Specifications by Use (Wt pct) ${ }^{[4]}$.

\begin{tabular}{lcccc} 
& Metallurgical & Chemical & Refractory & Foundry \\
\hline $\mathrm{Cr}_{2} \mathrm{O}_{3}$ & $>46$ & $>44$ & $30-40$ & $>44$ \\
\hline $\mathrm{Cr} / \mathrm{Fe}$ & $>2$ & $>1.5$ & $2-2.5$ & 2 \\
\hline $\mathrm{SiO}_{2}$ & $<10$ & $<3.5$ & 6 & $<4$ \\
\hline $\mathrm{Al}_{2} \mathrm{O}_{3}$ & & $25-30$ & \\
\hline $\mathrm{CaO}$ & & & $<0.5$ \\
\hline
\end{tabular}


The chlorination of a chromite ore $\left(38.2 \mathrm{Wt}\right.$ pct $\left.\mathrm{Cr}_{2} \mathrm{O}_{3}\right)$ and its concentrate $(51.1 \mathrm{Wt}$ pct $\mathrm{Cr}_{2} \mathrm{O}_{3}$ ) with $\mathrm{Cl}_{2}+\mathrm{C}$ between $600{ }^{\circ} \mathrm{C}$ and $1000{ }^{\circ} \mathrm{C}$ was carried out by Hussein and El-Barawi[10]. Between $800{ }^{\circ} \mathrm{C}$ and $1000{ }^{\circ} \mathrm{C}$, they found that the amount of carbon necessary to achieve almost full chlorination and volatilization of products, between $800{ }^{\circ} \mathrm{C}$ and $1000{ }^{\circ} \mathrm{C}$, for the chromite ore or its concentrate, was four and five times that of the stoichiometric amounts, respectively.

The decrease of reaction rate at temperatures higher than $800{ }^{\circ} \mathrm{C}$ was explained by possible decomposition of $\mathrm{COCl}_{2}$ formed in situ. The chlorination rate of iron was higher than that of chromium and attributed to favorable thermodynamic data. Finally, the authors suggested that it is possible to make products having $\mathrm{Cr} / \mathrm{Fe}$ ratios suitable for the ferro-chromium production by using short time carbochlorination of chromite ores at $600{ }^{\circ} \mathrm{C}$ or even at lower temperatures.

Hussein et al. ${ }^{[11]}$ studied the chlorination of $\mathrm{Cr}_{2} \mathrm{O}_{3}, \mathrm{Al}_{2} \mathrm{O}_{3}, \mathrm{MgO}, \mathrm{FeO}, \mathrm{Fe}_{2} \mathrm{O}_{3}$, of theirs mixtures and of synthetic compounds having the formula $\mathrm{Me}^{2+} \mathrm{Me}_{2}{ }^{3+} \mathrm{O}_{4}(\mathrm{M}=$ metal $)$ by using $\mathrm{Cl}_{2}+\mathrm{C}$. The behavior of a chromite ore and its concentrate was also tested using the same chlorination conditions, it was found to be in fair agreement with the results obtained from synthetic compounds.

The European patent $\mathrm{N}^{\circ} 0096241^{[12]}$ described the chlorination of oxidized materials by using $\mathrm{C}+\mathrm{Cl}_{2}$ in a fluidized bed at temperatures higher than $800{ }^{\circ} \mathrm{C}$ in order to produce the metal chlorides. The chlorination of chromite was performed between $1000{ }^{\circ} \mathrm{C}$ and $1100{ }^{\circ} \mathrm{C}$. The charge was composed of $20.25 \mathrm{~kg}$ of upgraded chromite ore and $7.75 \mathrm{~kg}$ of coke. A gas mixture of $\mathrm{Cl}_{2}+\mathrm{N}_{2}$ of $3 \mathrm{~m}^{3} / \mathrm{h}$ and containing 30 pct $\mathrm{Cl}_{2}$ was used. About $95 \%$ of all the oxides contained in the chromite were chlorinated and volatilized and the chlorides $\left(\mathrm{CrCl}_{3}, \mathrm{FeCl}_{2 / 3}, \mathrm{AlCl}_{3}\right.$, and $\left.\mathrm{MgCl}_{2}\right)$ were recovered in cyclones, whilst the dusts were composed of chromium and aluminum oxides.

\section{MATERIALS AND EXPERIMENTAL PROCEDURE}

The sample of chromite concentrate was obtained from an Albanian plant. The scanning electron microscopy 'SEM', X-ray diffraction 'XRD', microprobe and chemical analyses were used to determine the composition of this concentrate. Figure 2 gives some aspects of the chromite concentrate as revealed by SEM and microprobe analyses. Results of chemical and microprobe analyses concerning five major oxides of the chromite concentrate were grouped in Table II. This concentrate contained about $48 \% \mathrm{Cr}_{2} \mathrm{O}_{3}$ and was of a metallurgical grade characterized by a $\mathrm{Cr} / \mathrm{Fe}$ ratio close to 3.2. As it is shown in Figure 2 and Table II, the microprobe analysis suggested the presence of two different bodies in the concentrate. The chromite that is essentially constituted of chromium, iron, magnesium, aluminum oxides, and the gangue containing the oxides of magnesium and silicon along with small amounts of iron and aluminum oxide.

Combining the results of chemical and microprobe analysis, it resulted that chromite constituted about 80 pct of the concentrate. Based on the microprobe analysis data, the general formula of the chromite mineral could be the following : $\left(\mathrm{Fe}^{2+}{ }_{0.30}, \mathrm{Mg}_{0.70}\right)\left(\mathrm{Cr}_{1.56}, \mathrm{Al}_{0.37}\right.$, $\left.\mathrm{Fe}^{3+}{ }_{0.07}\right) \mathrm{O}_{4}$. This solid can also be formulated as : 30.9 pct $\mathrm{FeCr}_{2} \mathrm{O}_{4}, 51.0$ pct $\mathrm{MgCr}_{2} \mathrm{O}_{4}, 13.7$ pct $\mathrm{MgAl}_{2} \mathrm{O}_{4}$ and 4.4 pct $\mathrm{Fe}_{3} \mathrm{O}_{4}$. One may underline that these spinels have the same crystalline structure 
Table II. Composition of Chromite Concentrate (Wt pct).

\begin{tabular}{lccc} 
& Chemical Analyses & \multicolumn{2}{c}{ Microprobe } \\
\hline Oxide & (Average) & Chromite & Gangue \\
\hline $\mathrm{Cr}_{2} \mathrm{O}_{3}$ & 47.7 & 59.4 & 0.7 \\
\hline $\mathrm{FeO}$ & 13.4 & 13.9 & 3.7 \\
\hline $\mathrm{MgO}$ & 17.8 & 14.2 & 42.0 \\
\hline $\mathrm{Al}_{2} \mathrm{O}_{3}$ & 8.8 & 9.5 & 1.4 \\
\hline $\mathrm{SiO}_{2}$ & 7.1 & 0.1 & 39.7 \\
\hline
\end{tabular}

and lattice parameters making their identification, by XRD, almost impossible. References [11] and [13] also mentioned the presence of these compounds in the chromite ores.

Carbochlorination of chromite concentrate was performed using the horizontal experimental set-up schematized in Figure 3. This apparatus is composed of a gas metering unit followed by gas purification one and a horizontal furnace. A carbon furnace was added to eliminate any traces of oxygen contained in the gaseous mixture. The gaseous reaction products were recovered, in the condensers, by cooling and the spent gases were purified before their release to the atmosphere. The reaction products were examined by XRD, SEM and analyzed using conventional chemical methods.

The kinetic study was performed using samples of chromite mineral contained in the concentrate mentioned above. It was separated from the gangue by successive treatments using dense liquors. Kinetics of the carbochlorination of chromite with $\mathrm{Cl}_{2}+\mathrm{CO}$ was determined by thermogravimetric analysis 'TGA' technique schematized in Figure 4. Its main unit is a CAHN 1000 microbalance having a sensitivity of $10 \mu \mathrm{g}$. The carbochlorinating gas mixture was dried by $\mathrm{H}_{2} \mathrm{SO}_{4}$ and $\mathrm{CaCl}_{2}$ before its introduction into the reactor. About $40 \mathrm{mg}$ of chromite mineral was used for every test. The sample was uniformly distributed in a quartz crucible having a section of about 0.5 $\mathrm{cm}^{2}$. This crucible was hooked to the balance by quartz rods. It was heated in the carbochlorinating gas mixture by an electrical furnace having a heating rate of about $7{ }^{\circ} \mathrm{C} / \mathrm{min}$. The evolution of the samples' weight and temperature was continuously recorded. For the TGA isothermal runs, the sample was heated in nitrogen up to the desired temperature before the introduction of the carbochlorination gas mixture into the reactor.

\section{THERMODYNAMIC CONSIDERATIONS}

The evolution of free standard energy changes $\left(\Delta \mathrm{G}^{\circ}\right)$ as a function of temperature for the carbochlorination reactions (Eqs. 1 through 16) of major compounds contained in chromite concentrate was calculated. Data of Reference [14] and [15] were used for these calculations. Figure 5 traces the evolution of $\Delta \mathrm{G}^{\circ}$ versus temperature for the considered reactions. All the considered reactions were thermodynamically feasible in the explored temperature range. However, the carbochlorination reactions of iron oxides (Eqs. 7 to 9) were more favorable than that of chromium compounds (Eqs. 1 to 3 ) at temperatures higher than $500{ }^{\circ} \mathrm{C}$. 


\begin{tabular}{|c|c|c|c|c|c|c|c|c|c|c|c|c|c|c|}
\hline $1 / 3$ & $\mathrm{Cr}_{2} \mathrm{O}_{3}$ & $+\mathrm{Cl}_{2}$ & + & $\mathrm{CO}$ & $\rightarrow$ & & & & $2 / 3$ & $\mathrm{CrCl}_{3}$ & + & & $\mathrm{CO}_{2}$ & {$[1]$} \\
\hline $2 / 9$ & $\mathrm{FeCr}_{2} \mathrm{O}_{4}$ & $+\mathrm{Cl}_{2}$ & $+8 / 9$ & $\mathrm{CO}$ & $\rightarrow$ & $2 / 9$ & $\mathrm{FeCl}_{3}$ & + & $4 / 9$ & $\mathrm{CrCl}_{3}$ & + & $8 / 9$ & $\mathrm{CO}_{2}$ & [2] \\
\hline $1 / 4$ & $\mathrm{MgCr}_{2} \mathrm{O}_{4}$ & $+\mathrm{Cl}_{2}$ & + & $\mathrm{CO}$ & $\rightarrow$ & $1 / 4$ & $\mathrm{MgCl}_{2}$ & + & $1 / 2$ & $\mathrm{CrCl}_{3}$ & + & & $\mathrm{CO}_{2}$ & 3] \\
\hline $1 / 3$ & $\mathrm{Al}_{2} \mathrm{O}_{3}$ & $+\mathrm{Cl}_{2}$ & + & $\mathrm{CO}$ & $\rightarrow$ & & & & $2 / 3$ & $\mathrm{AlCl}_{3}$ & + & & $\mathrm{CO}_{2}$ & 47 \\
\hline $2 / 9$ & $\mathrm{FeAl}_{2} \mathrm{O}_{4}$ & $+\mathrm{Cl}_{2}$ & $+8 / 9$ & $\mathrm{CO}$ & $\rightarrow$ & $2 / 9$ & $\mathrm{FeCl}_{3}$ & + & $4 / 9$ & $\mathrm{AlCl}_{3}$ & + & $8 / 9$ & $\mathrm{CO}_{2}$ & 5] \\
\hline $1 / 4$ & $\mathrm{MgAl}_{2} \mathrm{O}_{4}$ & $+\mathrm{Cl}_{2}$ & + & $\mathrm{CO}$ & $\rightarrow$ & $1 / 4$ & $\mathrm{MgCl}_{2}$ & + & $1 / 2$ & $\mathrm{AlCl}_{3}$ & + & & $\mathrm{CO}_{2}$ & [6] \\
\hline $2 / 3$ & $\mathrm{FeO}$ & $+\mathrm{Cl}_{2}$ & $+2 / 3$ & $\mathrm{CO}$ & $\rightarrow$ & & & & $2 / 3$ & $\mathrm{FeCl}_{3}$ & 1 & $2 / 3$ & $\mathrm{CO}_{2}$ & 7] \\
\hline $2 / 9$ & $\mathrm{Fe}_{3} \mathrm{O}_{4}$ & $+\mathrm{Cl}_{2}$ & $+8 / 9$ & $\mathrm{CO}$ & $\rightarrow$ & & & & $2 / 3$ & $\mathrm{FeCl}_{3}$ & + & $8 / 9$ & $\mathrm{CO}_{2}$ & \\
\hline $1 / 3$ & $\mathrm{Fe}_{2} \mathrm{O}_{3}$ & $+\mathrm{Cl}_{2}$ & + & $\mathrm{CO}$ & $\rightarrow$ & & & & $2 / 3$ & $\mathrm{FeCl}_{3}$ & + & & $\mathrm{CO}_{2}$ & 9] \\
\hline $1 / 4$ & $\mathrm{MgFe}_{2} \mathrm{O}_{4}$ & $+\mathrm{Cl}_{2}$ & + & $\mathrm{CO}$ & $\rightarrow$ & $1 / 4$ & $\mathrm{MgCl}_{2}$ & + & $1 / 2$ & $\mathrm{FeCl}_{3}$ & + & & $\mathrm{CO}_{2}$ & [10] \\
\hline & $\mathrm{MgO}$ & $+\mathrm{Cl}_{2}$ & + & $\mathrm{CO}$ & $\rightarrow$ & & & & & $\mathrm{MgCl}_{2}$ & + & & $\mathrm{CO}_{2}$ & [11] \\
\hline & $\mathrm{Mg}_{2} \mathrm{SiO}_{4}$ & $+\mathrm{Cl}_{2}$ & + & $\mathrm{CO}$ & $\rightarrow$ & & $\mathrm{MgSiO}_{3}$ & + & & $\mathrm{MgCl}_{2}$ & + & & $\mathrm{CO}_{2}$ & [12] \\
\hline $1 / 4$ & $\mathrm{Mg}_{2} \mathrm{SiO}_{4}$ & $+\mathrm{Cl}_{2}$ & + & $\mathrm{CO}$ & $\rightarrow$ & $1 / 2$ & $\mathrm{MgCl}_{2}$ & + & $1 / 4$ & $\mathrm{SiCl}_{4}$ & + & & $\mathrm{CO}_{2}$ & [13] \\
\hline & $\mathrm{MnO}$ & $+\mathrm{Cl}_{2}$ & + & $\mathrm{CO}$ & $\rightarrow$ & & & & & $\mathrm{MnCl}_{2}$ & + & & $\mathrm{CO}_{2}$ & [14] \\
\hline $1 / 2$ & $\mathrm{SiO}_{2}$ & $+\mathrm{Cl}_{2}$ & + & $\mathrm{CO}$ & $\rightarrow$ & & & & $1 / 2$ & $\mathrm{SiCl}_{4}$ & + & & $\mathrm{CO}_{2}$ & [15] \\
\hline $1 / 2$ & $\mathrm{TiO}_{2}$ & $+\mathrm{Cl}_{2}$ & + & $\mathrm{CO}$ & $\rightarrow$ & & & & $1 / 2$ & $\mathrm{TiCl}_{4}$ & + & & $\mathrm{CO}_{2}$ & {$[16$} \\
\hline
\end{tabular}

The phase stability diagrams of $(\mathrm{Cr}, \mathrm{Fe}, \mathrm{Mg}, \mathrm{Al}, \mathrm{Si})-\mathrm{O}-\mathrm{Cl}$ systems ${ }^{[5,6]}$ suggested that the chlorides were the stable phases during the chlorination of oxides in the presence of a reducing atmosphere. Using carbon monoxide as reducing agent, the main products of the carbochlorination of chromium, iron, aluminum, magnesium and silicon oxides are expected to be $\mathrm{CrCl}_{3}, \mathrm{FeCl}_{3}, \mathrm{AlCl}_{3}$, $\mathrm{MgCl}_{2}$, and $\mathrm{SiCl}_{4}[5,6]$, respectively. The chromium oxychloride $\left(\mathrm{CrO}_{2} \mathrm{Cl}_{2}\right)$ is formed using a chlorinating gas mixture having high partial pressure of oxygen[16].

Figure 6 shows the evolution of vapor pressure of chlorides of major elements contained in chromite as a function of the temperature $[17,1]$. As shown by this figure, these chlorides are characterized by a wide difference of vapor pressure at a given temperature. Silicon, aluminum and ferric chlorides possess a high vapor pressure at temperature lower or equal to $300{ }^{\circ} \mathrm{C}$. This suggests that the carbochlorination of chromite compounds, at temperatures close to $500{ }^{\circ} \mathrm{C}$, will allows the volatilization of these chlorides leading to a residue rich in chromium compounds.

\section{RESULTS}

\section{A. Carbochlorination of Chromite Concentrate in the Horizontal Experimental Set-up}

Several grams of the chromite concentrate sample was treated in $\mathrm{Cl}_{2}+\mathrm{CO}\left(\mathrm{Cl}_{2} / \mathrm{CO}=1\right)$ between $500{ }^{\circ} \mathrm{C}$ and $1000{ }^{\circ} \mathrm{C}$ for a reaction time of 2 hours. Figure 7 gives the evolution of the percent weight loss (pct WL) of the sample versus temperature. The chromite concentrate starts to react with the carbochlorination gas mixture at $500{ }^{\circ} \mathrm{C}$. However, temperatures close to $1000{ }^{\circ} \mathrm{C}$ were required to achieve a complete reaction of the sample and volatilization of the reaction products. The residues were analyzed in order to determine their iron content. The extraction curve of iron as function of the 
temperature is also traced in Figure 7. Clearly, more than 45 pct of iron contained in the chromite was extracted at $500{ }^{\circ} \mathrm{C}$ for a reaction time of two hours. At higher temperatures, the extraction of iron increased almost linearly while that of pct weight loss augmented exponentially.

Another series of carbochlorination experiments of chromite concentrate was carried out between $500{ }^{\circ} \mathrm{C}$ and $850{ }^{\circ} \mathrm{C}$ for a reaction time of 2 and 8 hours. Chromium and iron contents of residues were determined by chemical analysis. In addition, the residues and condensates were characterized by XRD and SEM analyses. Figure 8 (a) traces pct WL of the chromite concentrate versus temperature for the two residence times. Small difference of pct WL was observed at temperatures lower than $700{ }^{\circ} \mathrm{C}$ when the reaction time was increased from 2 to 8 hours. The effects of temperature and the reaction time on the extraction of iron and chromium are given in Figure 8 (b). Results suggested that increase of the reaction time had a feeble effect on the extraction of iron in the whole-explored temperature range. The extraction of chromium at temperature lower or equal to 650 ${ }^{\circ} \mathrm{C}$ did not exceed 15 pct and was also slightly dependent on the reaction time. However, the extraction of chromium at temperature higher than $700{ }^{\circ} \mathrm{C}$ depended strongly on the temperature and reaction time. These results suggested that low temperatures and short reaction times might allow the selective extraction iron with limited losses of chromium.

Table III gives results of SEM and XRD analyses of several carbochlorination residues and condensates obtained at different reaction times and temperatures. Spinel $\left[(\mathrm{Fe}, \mathrm{Mg})(\mathrm{Cr}, \mathrm{Al})_{2} \mathrm{O}_{4}\right]$ was identified to be the main phase in the residue up to $800^{\circ} \mathrm{C}$. As mentioned earlier, it was difficult to detect the evolution of the spinels by XRD. Moreover, lattice parameters are almost independent from the simultaneous removal of divalent $\left(\mathrm{Fe}^{2+}, \mathrm{Mg}\right)$ and trivalent $\left(\mathrm{Fe}^{3+}, \mathrm{Cr}\right.$, and $\left.\mathrm{Al}\right)$ elements. On the other hand, the lacunaire spinels could be generated but the current experimental tools don't allow their detection. Chromium trichloride $\left(\mathrm{CrCl}_{3}\right)$ was identified in the condensate at temperatures higher or equal to $600{ }^{\circ} \mathrm{C}$. As shown by Table III, magnesium was detected in the condensates at $800{ }^{\circ} \mathrm{C}$ and it was identified as $\mathrm{MgCl}_{2} \cdot 6 \mathrm{H}_{2} \mathrm{O}$ due to the hygroscopic nature of $\mathrm{MgCl}_{2}$. These results confirm the possibility of selective separation of chlorides of $\mathrm{Mg}, \mathrm{Cr}$ from those of $\mathrm{Fe}$ and $\mathrm{Al}$ by a careful selective cooling of the gas phase.

Spectra of SEM analyses of the carbochlorination residues of chromite along with the semiquantitative analysis are shown in Figure 9. These results agree with those obtained by chemical analysis. Almost all the iron was removed at temperatures higher than $600{ }^{\circ} \mathrm{C}$. Total extraction of chromium was achieved at $800{ }^{\circ} \mathrm{C}$ for a reaction time of 8 hours and the residue was essentially composed of $\mathrm{Cl}, \mathrm{Mg}, \mathrm{Si}$, and $\mathrm{O}$. These results indicate that magnesium chloride (Table III) was only partially volatilized due to its low vapor pressure at $800{ }^{\circ} \mathrm{C}$ (Figure 6). Moreover, the presence of silicon in this residue suggests than the magnesium silicates were less reactive towards the $\mathrm{Cl}_{2}+\mathrm{CO}$ gas mixture[6]. Water leaching of this residue allows the separation of magnesium chloride from magnesium silicates.

Table IV summarizes the results obtained during the carbochlorination of chromite concentrate between $500{ }^{\circ} \mathrm{C}$ and $800{ }^{\circ} \mathrm{C}$. As shown in this table, the initial $\mathrm{Cr} / \mathrm{Fe}$ ratio is close to 3.2. This ratio increases as the carbochlorination temperature and time augments. It was doubled during the carbochlorination of the chromite concentrate at $500{ }^{\circ} \mathrm{C}$ with limited losses of chromium. This 
suggests that the carbochlorination of a chromite ore and/or a concentrate having a low $\mathrm{Cr} / \mathrm{Fe}$ ratio, around $500{ }^{\circ} \mathrm{C}$, will lead to the increase of this ratio to a satisfactory level for the ferro-chromium production specifications. The selective chlorination of iron could be also advantageous for chromite concentrates used for other applications.

In order to obtain an insight of the reaction mechanism of this complex solid, it was worthwhile to carry out a kinetic study of the carbochlorination of the chromite by $\mathrm{Cl}_{2}+\mathrm{CO}$ gaseous mixture using TGA at relatively high temperature. The following paragraphs describe these kinetic parameters as determined by TG analysis.

Table III : SEM and XRD Results of Carbochlorination Products of Chromite Concentrate for Different Temperatures and Reaction Time.

\begin{tabular}{|c|c|c|c|c|c|c|c|}
\hline \multirow{3}{*}{$\frac{\mathrm{T}}{{ }^{\circ} \mathrm{C}}$} & \multirow{3}{*}{$\frac{\mathrm{t}}{\mathrm{h}}$} & \multicolumn{2}{|c|}{ Residues } & \multicolumn{4}{|c|}{ Condensates } \\
\hline & & \multirow{2}{*}{ SEM } & \multirow{2}{*}{ XRD } & \multicolumn{2}{|l|}{$\mathrm{C}_{1}{ }^{*}$} & \multirow{2}{*}{$\begin{array}{c}\mathrm{C}_{2} \\
(\mathrm{SEM})\end{array}$} & \multirow{2}{*}{$\begin{array}{c}\mathrm{C}_{3} \\
(\mathrm{SEM})\end{array}$} \\
\hline & & & & $(\mathrm{SEM})$ & $(\mathrm{XRD})$ & & \\
\hline \multirow{2}{*}{500} & 2 & $\mathrm{Cr}, \mathrm{Mg}, \mathrm{Si}, \mathrm{Al}, \mathrm{Fe}, \mathrm{Cl}$ & \multirow{2}{*}{$(\mathrm{Fe}, \mathrm{Mg})(\mathrm{Cr}, \mathrm{Al})_{2} \mathrm{O}_{4}$} & $\mathrm{Cl}, \mathrm{Fe}, \varepsilon \mathrm{Cr}$ & & & \\
\hline & 8 & $\mathrm{Cr}, \mathrm{Mg}, \mathrm{Si}, \mathrm{Al}, \mathrm{Cl}, \mathrm{Fe}$ & & $\mathrm{Cl}, \mathrm{Fe}, \varepsilon \mathrm{Cr}$ & & & \\
\hline \multirow{2}{*}{600} & 2 & $\mathrm{Cr}, \mathrm{Si}, \mathrm{Mg}, \mathrm{Al}, \mathrm{Cl}, \mathrm{Fe}$ & \multirow{2}{*}{$(\mathrm{Fe}, \mathrm{Mg})(\mathrm{Cr}, \mathrm{Al})_{2} \mathrm{O}_{4}$} & $\mathrm{Cl}, \mathrm{Fe}, \mathrm{Cr}$ & \multirow{2}{*}{$\mathrm{CrCl}_{3}$} & $\mathrm{Cl}, \mathrm{Fe}, \mathrm{Cr}$ & \\
\hline & 8 & $\mathrm{Cr}, \mathrm{Si}, \mathrm{Mg}, \mathrm{Al}, \mathrm{Cl}, \mathrm{Fe}$ & & $\mathrm{Cl}, \mathrm{Fe}, \mathrm{Cr}, \mathrm{Al}$ & & $\mathrm{Cl}, \mathrm{Fe}, \mathrm{Cr}, \mathrm{Al}$ & \\
\hline \multirow{2}{*}{700} & 2 & $\mathrm{Cr}, \mathrm{Si}, \mathrm{Mg}, \mathrm{Cl}, \mathrm{Al}, \mathrm{Fe}$ & \multirow{2}{*}{$(\mathrm{Fe}, \mathrm{Mg})(\mathrm{Cr}, \mathrm{Al})_{2} \mathrm{O}_{4}$} & $\mathrm{Cl}, \mathrm{Fe}, \mathrm{Cr}$ & \multirow{2}{*}{$\mathrm{CrCl}_{3}$} & $\mathrm{Cl}, \mathrm{Fe}, \mathrm{Cr}, \mathrm{Al}$ & $\mathrm{Cl}, \mathrm{Cr}, \mathrm{Fe}$ \\
\hline & 8 & $\mathrm{Cl}, \mathrm{Cr}, \mathrm{Mg}, \mathrm{Si}, \mathrm{Al}, \mathrm{Ca}, \mathrm{Fe}$ & & $\mathrm{Cl}, \mathrm{Cr}, \mathrm{Fe}, \mathrm{Al}$ & & $\mathrm{Cl}, \mathrm{Cr}, \mathrm{Fe}, \mathrm{Al}$ & $\mathrm{Cl}, \mathrm{Cr}, \mathrm{Al}, \mathrm{Fe}$ \\
\hline \multirow{2}{*}{800} & 2 & $\mathrm{Cl}, \mathrm{Cr}, \mathrm{Mg}, \mathrm{Si}, \mathrm{Al}, \mathrm{Ca}$ & $(\mathrm{Fe}, \mathrm{Mg})(\mathrm{Cr}, \mathrm{Al})_{2} \mathrm{O}_{4}$ & $\mathrm{Cl}, \mathrm{Mg}$ & \multirow{2}{*}{$\mathrm{MgCl}_{2}$} & $\mathrm{Cl}, \mathrm{Cr}, \mathrm{Fe}, \mathrm{Al}, \mathrm{Mg}$ & $\mathrm{Cl}, \mathrm{Cr}, \mathrm{Al}$ \\
\hline & 8 & $\mathrm{Cl}, \mathrm{Mg}, \mathrm{Si}, \mathrm{Ca}$ & $\mathrm{MgCl}_{2}{ }^{* *}$ & $\mathrm{Cl}, \mathrm{Mg}$ & & $\mathrm{Cl}, \mathrm{Cr}, \mathrm{Al}, \mathrm{Fe}$ & $\mathrm{Cl}, \mathrm{Cr}, \mathrm{Al}$ \\
\hline
\end{tabular}

* Condensate $\mathrm{N}^{\circ} 1,2$ and 3 were recovered at different temperatures of the condenser,

** Magnesium chloride was identified as $\mathrm{MgCl}_{2} \cdot 6 \mathrm{H}_{2} \mathrm{O}$.

Table IV : Evolution of $\mathrm{Cr} / \mathrm{Fe}$ Ratio in the Carbochlorination Residues of Chromite Concentrate as a Function of the Treatment's Conditions.

\begin{tabular}{ccccc}
\hline $\mathrm{T},{ }^{\circ} \mathrm{C}$ & Time, $\mathrm{h}$ & $\mathrm{Cr}, \mathrm{Wt}$ Pct & Fe, Wt Pct & $\mathrm{Cr} / \mathrm{Fe}$ \\
\hline \multirow{2}{*}{ Raw Sample } & - & 34.2 & 10.8 & $\mathbf{3 . 2}$ \\
\hline \multirow{2}{*}{500} & 2 & 40.9 & 6.3 & $\mathbf{6 . 5}$ \\
& 8 & 35.7 & 6.6 & $\mathbf{5 . 4}$ \\
\hline \multirow{2}{*}{600} & 2 & 38.5 & 4.4 & $\mathbf{8 . 8}$ \\
& 8 & 36.7 & 3.4 & $\mathbf{1 0 . 8}$ \\
\hline \multirow{2}{*}{700} & 2 & 39.9 & 3.7 & $\mathbf{1 0 . 8}$ \\
& 8 & 35.2 & 2.9 & $\mathbf{1 2 . 1}$ \\
\hline \multirow{2}{*}{800} & 2 & 38.7 & 1.5 & $\mathbf{2 5 . 8}$ \\
\hline
\end{tabular}




\section{B. Kinetics of Carbochlorination of Chromite Mineral}

\section{Non isothermal TG analysis}

The non-isothermal carbochlorination of chromite mineral was investigated from room temperature to about $975{ }^{\circ} \mathrm{C}$ using the apparatus described in Figure 4. Figure 10 gives pct WL as a function of temperature at temperatures higher than $400{ }^{\circ} \mathrm{C}$. The chromite started to react with the carbochlorinating gas mixtures at about $500{ }^{\circ} \mathrm{C}$. Total reaction of the chromite with $\mathrm{Cl}_{2}+\mathrm{CO}$ and volatilization of the reaction products were achieved at about $975^{\circ} \mathrm{C}$. The pct WL curve had a plateau of weight loss $\left(\approx 35\right.$ pct WL) observed at about $775{ }^{\circ} \mathrm{C}$ prior to a sharp increase of pct WL at temperatures higher than $825^{\circ} \mathrm{C}$. The derivative of the pct WL traced in Figure 10 shows clearly the existence of two regions of distinct kinetics. The pct WL observed corresponds roughly to the calculated weight loss for the carbochlorination of $\mathrm{Fe}_{3} \mathrm{O}_{4}$ and $\mathrm{FeCr}_{2} \mathrm{O}_{4}$ (see $\mathrm{L}_{1}$ in Figure 10) both contained in the chromite. This couldn't be attributed to the difference between the rate of $\mathrm{MgCl}_{2}$ formation and that of its volatilization. Moreover, the slow down of the reaction rate at about 35 pct WL was also observed during the oxychlorination of chromite by $\mathrm{Cl}_{2}+\mathrm{O}_{2}$ where the volatilization rate of $\mathrm{MgCl}_{2}$ was higher than that of its formation ${ }^{[6,8]}$.

\section{Effect of gas flow rate}

It was studied at $1000{ }^{\circ} \mathrm{C}$ during the carbochlorination of chromite with a gas mixture having an equimolar content of carbon monoxide and chlorine. The total flow rate of $\mathrm{Cl}_{2}+\mathrm{CO}$ was varied from 8 to $100 \mathrm{~L} / \mathrm{h}$. It was interesting to follow the evolution of the reaction rate as function of gas flow rate at different pct WL of the sample. Figure 11 gives a typical example of the reaction rate evolution versus flow rate for the WL range up to $25 \mathrm{pct}$ and between 65 to 90 pct. For a gas flow rate higher than $20 \mathrm{~L} / \mathrm{h}$, the initial reaction rate was at least 5 times faster than that obtained for a WL higher than 65 pct. On the other hand, the reaction rate seems to be almost independent of the gas flow rate for values higher than $60 \mathrm{~L} / \mathrm{h}$ whichever was the pct WL chosen. A gas flow rate of $80 \mathrm{~L} / \mathrm{h}$ (linear gas velocity ' $\mathrm{V}_{\mathrm{g}}$ ' $=1.1 \mathrm{~cm} / \mathrm{s}$ ) was used to study the effect of other parameters on the carbochlorination of chromite.

\section{Effect of temperature}

The effect of temperature during the isothermal carbochlorination tests of chromite sample was studied between $750{ }^{\circ} \mathrm{C}$ and $1050{ }^{\circ} \mathrm{C}$. Results are given in Figure 12 as pct WL versus time. About 400 minutes were required to carbochlorinate 90 pct of the sample at $775{ }^{\circ} \mathrm{C}$, while only 5 minutes were necessary to reach the same pct WL at $1050^{\circ} \mathrm{C}$. On the other hand, the reaction rate up to 35 pct WL was rapid in the investigated temperature range.

Different kinetics equations ${ }^{[18]}$ were used to fit the experimental data concerning the evolution of the reaction extent (ratio of weight of the reacted fraction to initial weight) as function of time. The best mathematical fitting of the experimental data was obtained using equations 17 and 18 . As mentioned before, the chlorination of $(\mathrm{Fe}, \mathrm{Mg})(\mathrm{Cr}, \mathrm{Al})_{2} \mathrm{O}_{4}$ proceeds in two steps. The first is up to $35 \%$ of weight loss that corresponds roughly to the chlorination of $\mathrm{FeCr}_{2} \mathrm{O}_{4}$ characterized by a high reaction rate. The second step is that of the chlorination of $\mathrm{Mg}(\mathrm{Cr}, \mathrm{Al})_{2} \mathrm{O}_{4}$ with a weight loss of 35 to $100 \%$ and characterized by a relatively slow rate of reaction. 
Figure 13 shows the mathematical fitting of experimental data for a reaction extent of 5 to 35 $\%$ weight loss. Up to $850{ }^{\circ} \mathrm{C}$, the reaction progress according to equation [17] with a correlation coefficient of 0.971. Equation [17] represents the pore diffusion control in reaction of porous or nonporous solids with a porous product layer of spheres. This suggests that the diffusion of iron and chromium in the spinel could be the slowest step during the chlorination of the chromite. At temperatures higher than $925{ }^{\circ} \mathrm{C}$, Figure $13 \mathrm{~b}$ suggests that the experimental data fit equation [18] with a correlation coefficient of 0.991 . Equation [18] is considered to describe a reaction controlled by the chemical reaction in the case of shrinking non-porous particles (with or without a solid porous product) and porous particles with unchanged overall sizes. This suggests that the chlorination of chromite to be controlled by the chemical reaction. This change may be attributed to the presence of non-volatilized $\mathrm{CrCl}_{3}$, see figure 6 , and/or molten magnesium chloride that offers a privileged access for the chlorination of unreacted portion of chromite ${ }^{6]}$. Such hypothesis is partially confirmed by the change of the apparent activation energy from 135 to $74 \mathrm{~kJ} / \mathrm{mol}$ around $925{ }^{\circ} \mathrm{C}$.

For the chlorination of $\mathrm{Mg}(\mathrm{Cr}, \mathrm{Al})_{2} \mathrm{O}_{4}$ and the rest of the sample, Eq. [17] seem to be the most appropriate to describe the evolution of the reaction extent as function of time for the temperature range of $750{ }^{\circ} \mathrm{C}$ to $1050{ }^{\circ} \mathrm{C}$ with a correlation coefficient of 0.996 (Figures $14 \mathrm{a}$ and b).

$$
\begin{array}{lll}
1-3(1-X)^{2 / 3}+2(1-X) & = & k t \\
1-(1-X)^{1 / 3} & = & k t
\end{array}
$$

where $\mathrm{k}=$ constant and $\mathrm{t}=$ chlorination time.

The effect of temperature on the carbochlorination was estimated thanks to Arrhenius diagram. Figure 15 gives plots for pct WL ranging from 5 to 30 pct and from 40 to 90 pct. Apparent activation energy ' $\mathrm{E}_{\mathrm{a}}$ ' of about 135 and $74 \mathrm{~kJ} / \mathrm{mol}$ were calculated for the carbochlorination of chromite up to 30 pct WL below and above $925{ }^{\circ} \mathrm{C}$. A higher value of $\mathrm{E}_{\mathrm{a}}$ of about $195 \mathrm{~kJ} / \mathrm{mol}$ characterizes the carbochlorination process between 40 and 90 pct WL.

\section{Effect of $\left(\mathrm{Cl}_{2}+\mathrm{CO}\right)$ partial pressure}

To determine this effect a series of the isothermal tests was carried out at $1000{ }^{\circ} \mathrm{C}$. A gas mixture of $\mathrm{Cl}_{2}+\mathrm{CO}+\mathrm{N}_{2}$ having a linear velocity of $1.10 \mathrm{~cm} / \mathrm{s}$ was used. The $\mathrm{Cl}_{2} / \mathrm{CO}$ molar ratio was kept constant and equal to one, while $\left(\mathrm{Cl}_{2}+\mathrm{CO}\right)$ content was varied from 15 to 100 pct. Figure 15 represents the obtained data plotted as pct WL versus time. Results show that the time required to obtain a given pct WL decreased with the raise of the pct $\left(\mathrm{Cl}_{2}+\mathrm{CO}\right)$ in the gas mixtures. The evolution of the reaction rate as a function of the partial pressure of $\left(\mathrm{Cl}_{2}+\mathrm{CO}\right)$ for the two pct WL ranges is traced in Figure 15 (b). The apparent reaction orders obtained were 1.30 and 1.40 for $5 \leq$ pct WL $\leq 30$ and $40 \leq$ pct $\mathrm{WL} \leq 60$, respectively. These non-integer values may reflect a complex mechanism involving probably several intermediate steps.

\section{Effect of $\mathrm{Cl}_{2} /\left(\mathrm{Cl}_{2}+\mathrm{CO}\right)$ ratio}

The effect of $\mathrm{Cl}_{2} /\left(\mathrm{Cl}_{2}+\mathrm{CO}\right)$ molar ratio was also studied at $1000{ }^{\circ} \mathrm{C}$ using a $\mathrm{Cl}_{2}+\mathrm{CO}$ gas mixture having a $\mathrm{V}_{\mathrm{g}}$ of $1.10 \mathrm{~cm} / \mathrm{s}$. The chlorine content was varied from 10 to 90 pct. Figures 16 (a) and (b) show the data plotted as pct WL against time. About 9 minutes were required to obtain 80 pct 
WL of the sample using a gas mixture containing 10 or 90 pct $\mathrm{Cl}_{2}$. The evolution of the reaction rate as function of $\mathrm{Cl}_{2} /\left(\mathrm{Cl}_{2}+\mathrm{CO}\right)$ for $5 \leq$ pct $\mathrm{WL} \leq 30$ and $40 \leq$ pct $\mathrm{WL} \leq 60$ was illustrated in Figure 16 (c). It indicates that the maximum reaction rate was obtained for a gas mixture having almost an equimolar $\mathrm{Cl}_{2}$ and $\mathrm{CO}$ content.

\section{CONCLUSIONS}

Carbochlorination of chromite at about $600{ }^{\circ} \mathrm{C}$ could be used for upgrading the chromium concentrates and ores. More than 60 pct of iron was extracted during the treatment of a chromite concentrate at this temperature during two hours with a chromium extraction of less than 5 pct. Consequently, the $\mathrm{Cr} / \mathrm{Fe}$ ratio was at least doubled. The reaction time and temperature had a slight effect on the kinetics of iron removal. While, total extraction of chromium was achieved at temperatures higher than $750{ }^{\circ} \mathrm{C}$ and it depended on the temperature and reaction duration.

Partial removal of magnesium as $\mathrm{MgCl}_{2}$ occurred at temperatures higher than $800{ }^{\circ} \mathrm{C}$. Carbochlorination of the chromite concentrates at these temperatures followed by a controlled cooling of the gas phase allows selective separation of chlorides of major elements contained in the chromite.

The effect of temperature on the reaction of the chromite mineral with $\mathrm{Cl}_{2}+\mathrm{CO}$ between 750 ${ }^{\circ} \mathrm{C}$ and $1050{ }^{\circ} \mathrm{C}$ changes with the reaction progress. The average value of the apparent activation energy was about 135 and $74 \mathrm{~kJ} / \mathrm{mol}$ for reaction extents up to 0.35 at temperatures lower and higher than $925^{\circ} \mathrm{C}$, respectively. The carbochlorination process for reaction extent higher than 0.4 proceeded with a value of $E_{a}$ of about $195 \mathrm{~kJ} / \mathrm{mol}$.

The mean apparent reaction order of the chromite carbochlorination was about 1.35 with respect to $\mathrm{Cl}_{2}+\mathrm{CO}$ at $1000{ }^{\circ} \mathrm{C}$. At this temperature, a maximum reaction rate was obtained with a carbochlorinating gas mixture having a $\mathrm{Cl}_{2} /\left(\mathrm{Cl}_{2}+\mathrm{CO}\right)$ ratio of 0.5 .

\section{ACKNOWLEDGMENTS}

This work was performed in the frame of contract $\mathrm{N}^{\circ}$ BRE2-CT92-0173 thanks to the financial support of the European Union (DG-XII). The authors thank Dr. H. L. Schmidt for discussion, suggestion and help.

They also would like to thank Dr. J. C. Mugica, Dr. R. Solozabal (INASMET, San Sebastian, Spain) and Dr. M. Coelho (INETI, Lisbon, Portugal) for technical discussions. Authors are indebted to Dr. A. Bonazébi, Dr. M. Djona, Dr. S. Ivanaj, Dr. N. Menad, Dr. N. Mirghaffari for discussions and help on different subjects and to Mrs. C. Richard for technical and administrative support. 


\section{REFERENCES}

1. J. Amiel, J. Aubry, A. Chrétien, CL. Duval, R. Duval, W. Freundlich, L. Malaprade, P. Pasacal., Nouveau traité de chimie minérale, tome XIV (Masson et Cie, eds., 1959), 37, 135 and 152.

2 Anonymous: Thermochemical and Physical Properties (TAPP, version 2.1), E S Microware, Inc. 2234 Wade Court, Hamilton, OH 45013.

3 A.M. Lejus: Thesis Doctorat es Sciences Physiques, Faculté des Sciences de l'Université de Paris, 1964.

4 P.W. Harben:The industrial minerals handybook, $2^{\text {nd }}$ edition, CRC Press, Published by Industrial Minerals Divisions, Metal Bulletin PLC, London, United Kingdom, 1995, pp. 47-51.

5 I. Gaballah, N. Kanari and N. Menad: Fifth Report of European Union Contract No BRE2CT92-0173, Institut National Polythecnique de Lorraine, Laboratoire Environnement et Mineralurgie, Nancy, France, October 1995, 79 pages.

6 N. Kanari: Ph.D. Thesis, Institut National Polythechnique de Lorraine, Laboratoire Environnement et Mineralurgie, Nancy, France, November 1995, 209 pages.

7 N. Kanari and I. Gaballah: Paper presented at Proc. of the TMS Annual Meeting, Orlando, Florida, February 9-13, 1997, EPD Congress 1997, Ed. by B. Mishra, Pub. by TMS, pp. 57-71.

8 N. Kanari and I. Gaballah: Paper presented at Proc. of the TMS Annual Meeting, San Antonio, Texas, February 15-19, 1998, Light Metals 1998, Ed. by Barry J. Welch, Published by TMS, pp. 1333-1341.

9 A.S Athawale and V.A. Altekar: Trans. Indian Inst. Metals, 1969, 22, pp. 29-37.

10 M.K. Hussein and K. El-Barawi: Trans.-Inst. Min. Metall., 1971, Sect. C, 80, pp. C7-C11.

11 M.K. Hussein, H. Winterhager, R. Kammel and K. El-Barawi: Trans.-Inst. Min. Metall., 1974, Sect. C, 83, pp. C154-C160.

12 M. Robinson and A.D. Crosby: Eur. Pat. Appl. EP, Nº 096 241, 21 December 1983, 25 pages.

13 V.A. Martirosyan: Arm. Khim. Zh., 1978, 31 (2-3), pp. 100-106.

14 I. Barin, Thermochemical data of pure substances, 1989, Parts I and II, VCH.

15 A. Roine: in Outokumpu HSC Chemistry for Windows, Version 2.0, Outokumpu Research, Pori, Finland, May 1994.

16 I. Gaballah, S. Ivanaj, and N. Kanari : Metallurgical and Materials Transactions A, 1998, 29A, pp. 1299-1308.

17 Anonymous : Handbook of Chemistry and Physics, (66 th edition, Eds. R.C. Weast, M.J. Astle, and W.H. Beyer, CRC Press, Florida, USA, 1986), pp. D193-D194.

18 J. Szekely, J.W. Evans and H.Y. Sohn, in Gas-Solid Reactions, Academic Press, New York, NY. 1976, pp. 68-70, 73-88, 109-131 and 232-235. 


\title{
A Study of the Chromite Carbochlorination Kinetics
}

\author{
N. KANARI, E. ALLAIN* and I. GABALLAH \\ Mineral Processing and Environmental Engineering team, \\ LEM $^{\text {a }}$, CNRS $^{b}$ UMR 7569, ENSGc ${ }^{\mathrm{c}}$ INPL ${ }^{\mathrm{d}}$, BP 40, 54501 Vandœuvre, France \\ * University of Missouri-Rolla, School of Mines and Metallurgy, Center for Pyrometallurgy \\ 210 Fulton Hall, 65401 Rolla, MO, USA
}

\section{FIGURE CAPTIONS}

Figure 1 : Spinel chromite structure[3].

Figure 2 : Results of microprobe and SEM analyses of chromite concentrate.

Figure 3 : Horizontal experimental set-up.

Figure 4 : Thermogravimetric experimental set-up.

Figure 5 : Evolution of standard free energy changes as function of temperature for the carbochlorination of compounds of chromite concentrate ${ }^{[14,15] .}$

Figure 6 : Evolution of vapor pressure of several chlorides [17, 1].

Figure 7 : Evolution of pct WL and extraction of iron as a function of temperature during carbochlorination of chromite concentrates for two hours.

Figure 8 : Evolution of pct WL (a) and extraction of $\mathrm{Cr}$ and $\mathrm{Fe}(\mathrm{b})$ as a function of temperature and reaction time during carbochlorination of chromite.

Figure 9 : Semi-quantitative analyses of the carbochlorination residues of chromite concentrate at different temperatures for a reaction time of 2 and 8 hours.

Figure 10 : Evolution of pct WL of the sample and derivative of WL versus temperature during nonisothermal carbochlorination of chromite.

Figure 11 : Effect of gas flow rate on the carbochlorination of chromite at $1000{ }^{\circ} \mathrm{C}$.

Figure 12 : Isotherms of carbochlorination of chromite from (a) $750{ }^{\circ} \mathrm{C}$ to $875{ }^{\circ} \mathrm{C}$ and (b) $900{ }^{\circ} \mathrm{C}$ to $1050{ }^{\circ} \mathrm{C}$.

Figure 13 : Mathematical fitting of the carbochlorination data ( $X \leq 0.35)$ using Eq. [17 and 18].

Figure 14 : Mathematical fitting of the carbochlorination data $(0.4 \leq X \leq 0.9)$ using Eq. [17].

Figure 15 : Arrhenius diagrams of the chromite carbochlorination.

Figure 16 : Isotherms of carbochlorination of chromite at $1000{ }^{\circ} \mathrm{C}(a)$ using various $\mathrm{Cl}_{2}+\mathrm{CO}$ contents and $(b)$ apparent reaction orders with respect to $\mathrm{Cl}_{2}+\mathrm{CO}$.

Figure 17 : Carbochlorination of chromite at $1000^{\circ} \mathrm{C}$.

(a) and (b): pct WL versus temperature for different $\mathrm{Cl}_{2}$ contents in $\mathrm{Cl}_{2}+\mathrm{CO}$ gas mixture

(c) : reaction rate against $\mathrm{Cl}_{2} /\left(\mathrm{Cl}_{2}+\mathrm{CO}\right)$ molar ratio.

\section{TABLE CAPTIONS}

Table I : Chromite Specifications by Use (Wt pct) ${ }^{[4]}$

Table II : Composition of Chromite Concentrate (Wt pct).

Table III : SEM and XRD Results of Carbochlorination Products of Chromite

Concentrate for Different Temperatures and Reaction Time.

Table IV : Evolution of $\mathrm{Cr} / \mathrm{Fe}$ Ratio in the Carbochlorination Residues of Chromite Concentrate as a Function of the Treatment's Conditions 


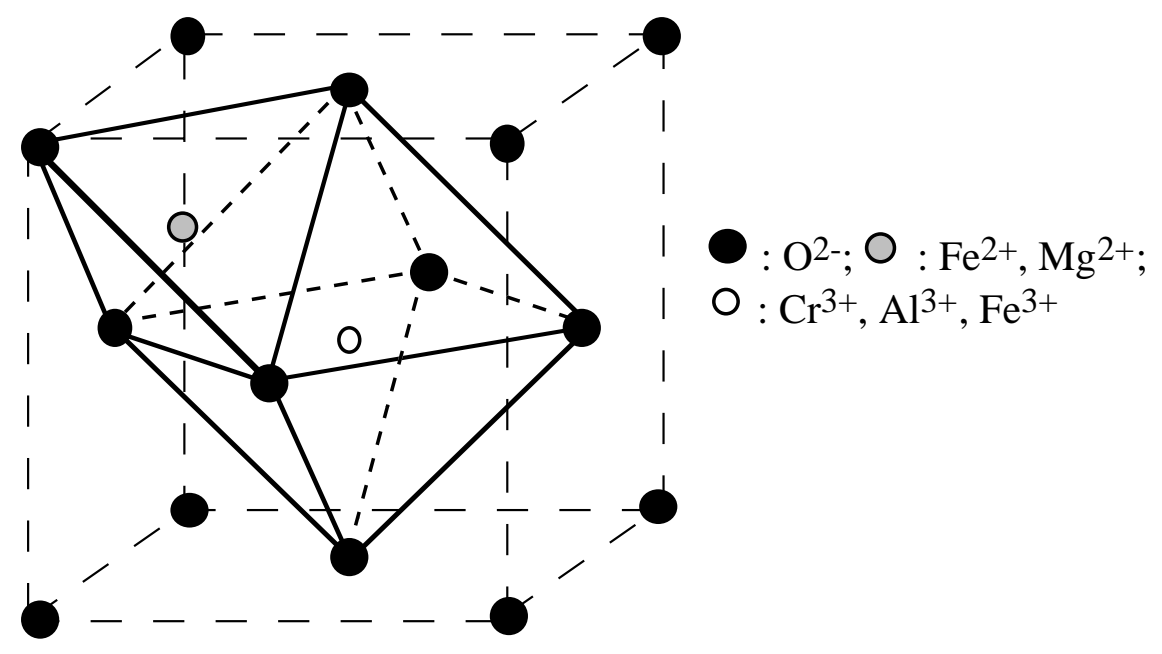

Figure 1 : Spinel structure of chromite [3].
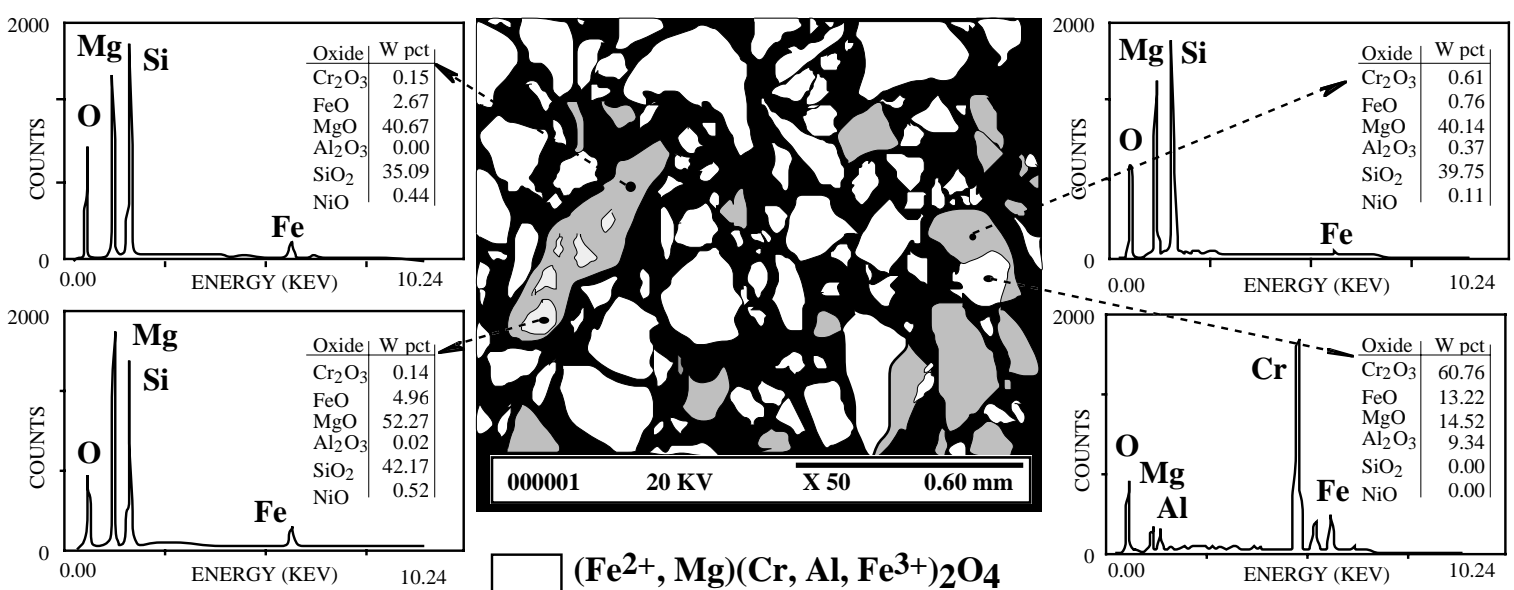

$\left(\mathrm{Fe}^{2+}, \mathrm{Mg}\right)\left(\mathrm{Cr}, \mathrm{Al}, \mathrm{Fe}^{3+}\right)_{2} \mathrm{O}_{4}$

$(\mathrm{Mg}, \mathrm{Fe})_{2} \mathrm{SiO}_{4} \& \mathrm{Mg}_{3} \mathrm{Si}_{2} \mathrm{O}_{5}(\mathrm{OH})_{4}$

Figure 2 : Results of microprobe and SEM analyses of chromite concentrate.

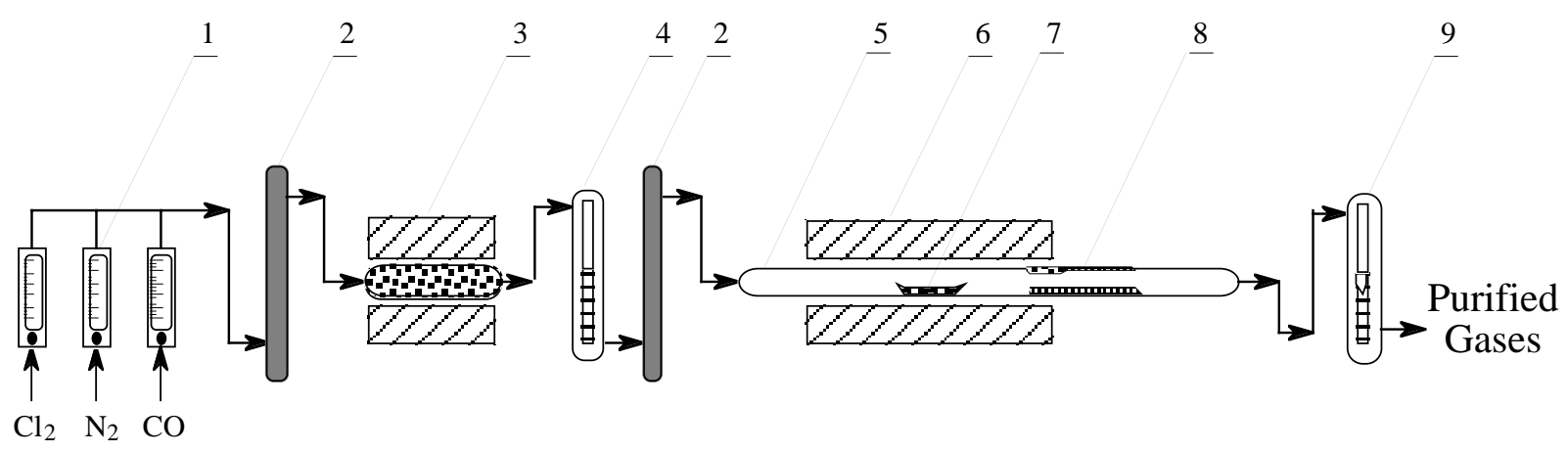
1. Flowmeters
2. $\mathrm{P}_{2} \mathrm{O}_{5}$ columns
3. Carbon furnace
4. Drying column
5. Quartz reactor
6. Furnace
7. Sample boat
8. Condenser
9. $\mathrm{NaOH}$ column

Figure 3 : Horizontal experimental set-up. 


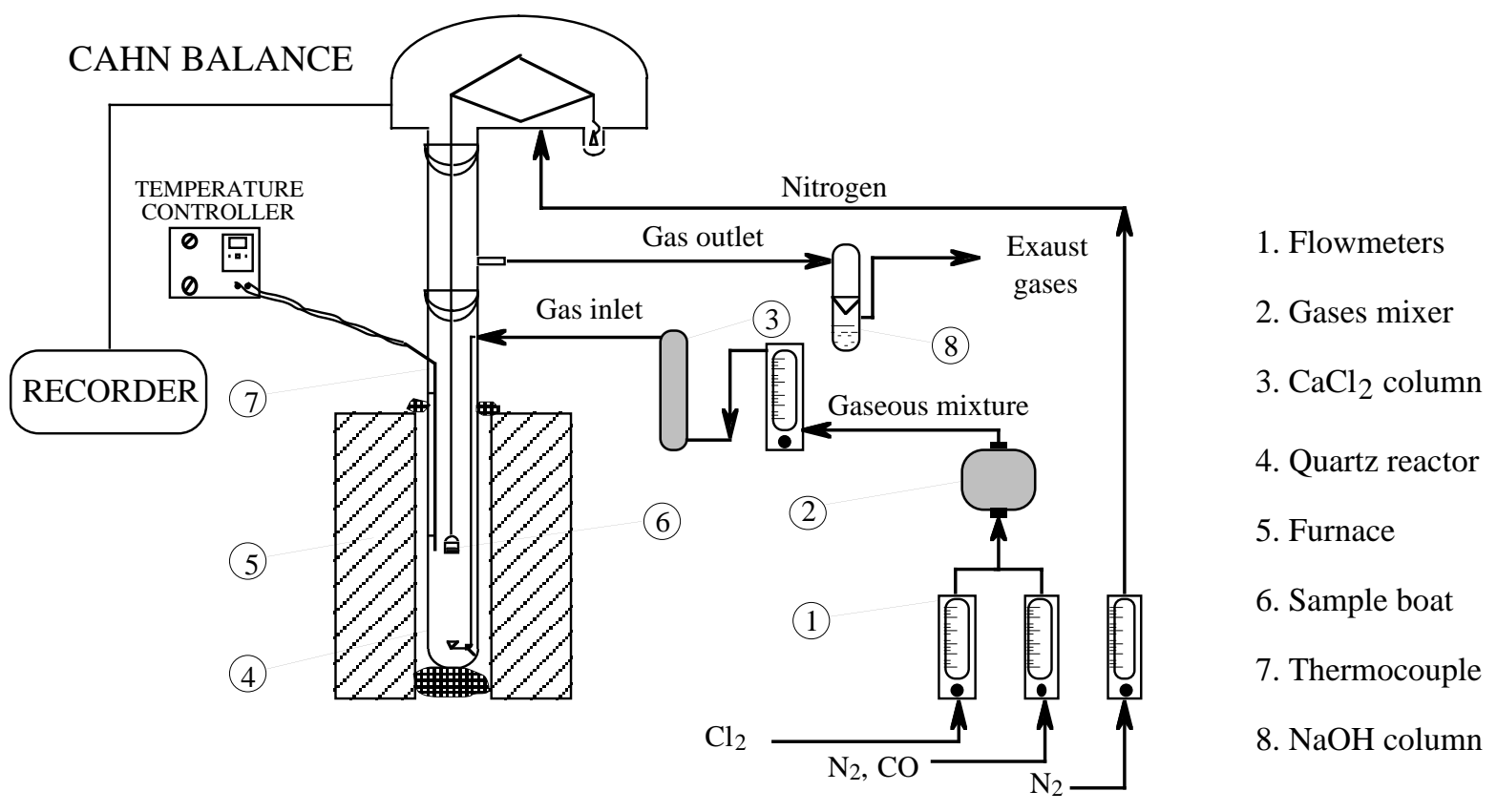

Figure 4 : Thermogravimetric experimental set-up.

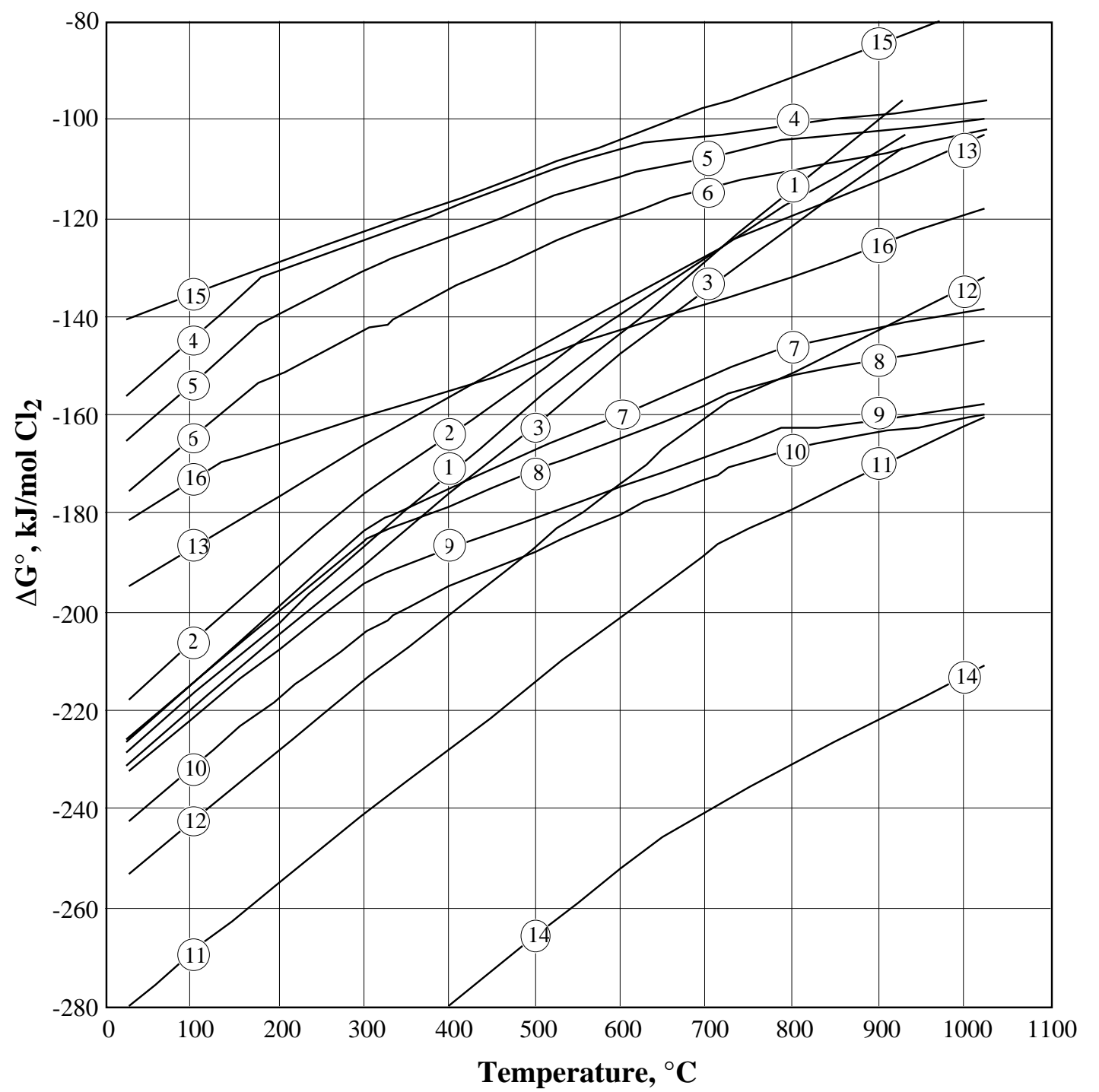

Figure 5 : Evolution of standard free energy changes as function of temperature for the carbochlorination of compounds of chromite concentrate[14, 15] 


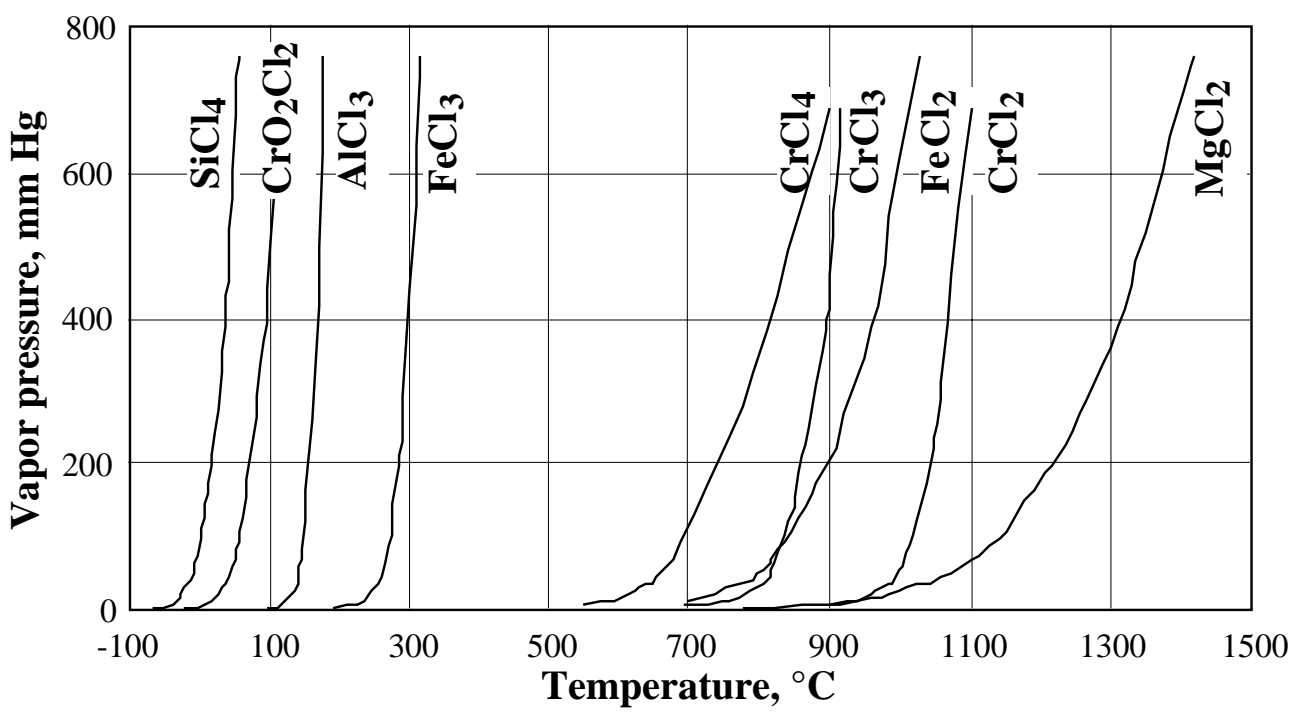

Figure 6 : Evolution of vapor pressure of several chlorides $[17,1]$.

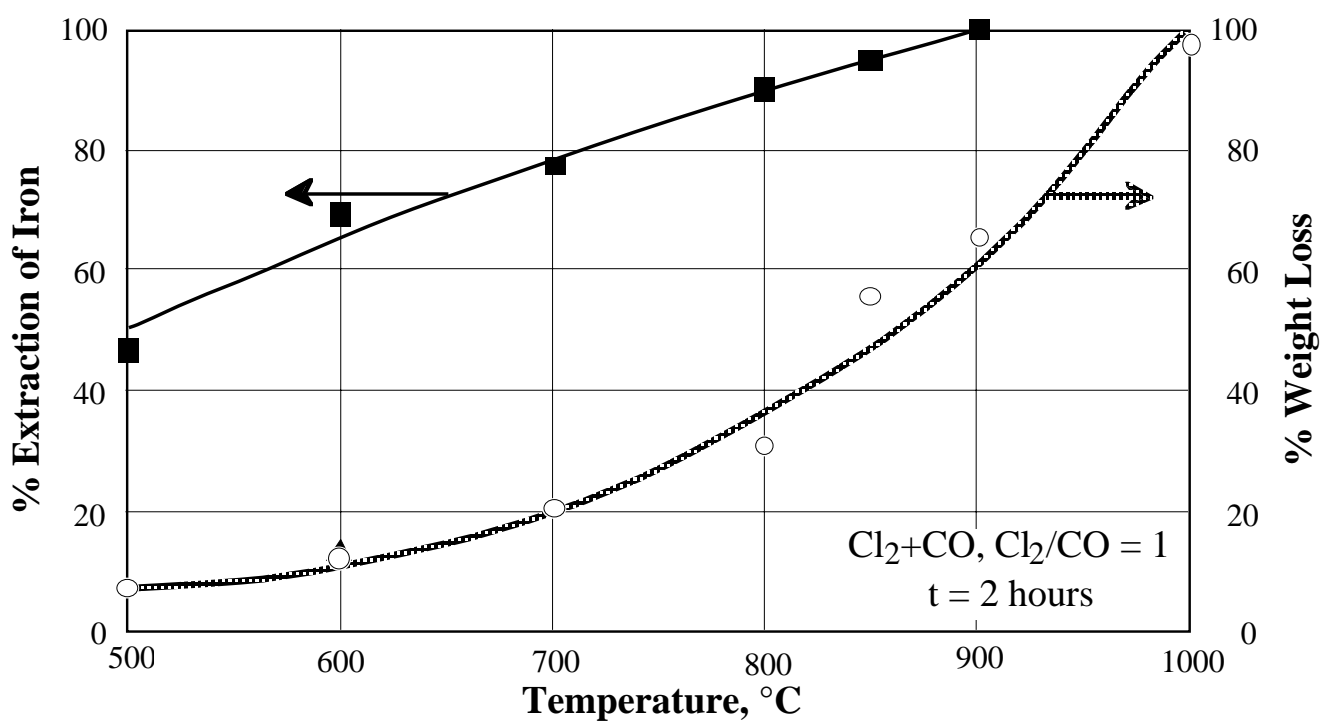

Figure 7 : Evolution of pct WL and extraction of iron as a function of temperature during carbochlorination of chromite concentrates for two hours. 

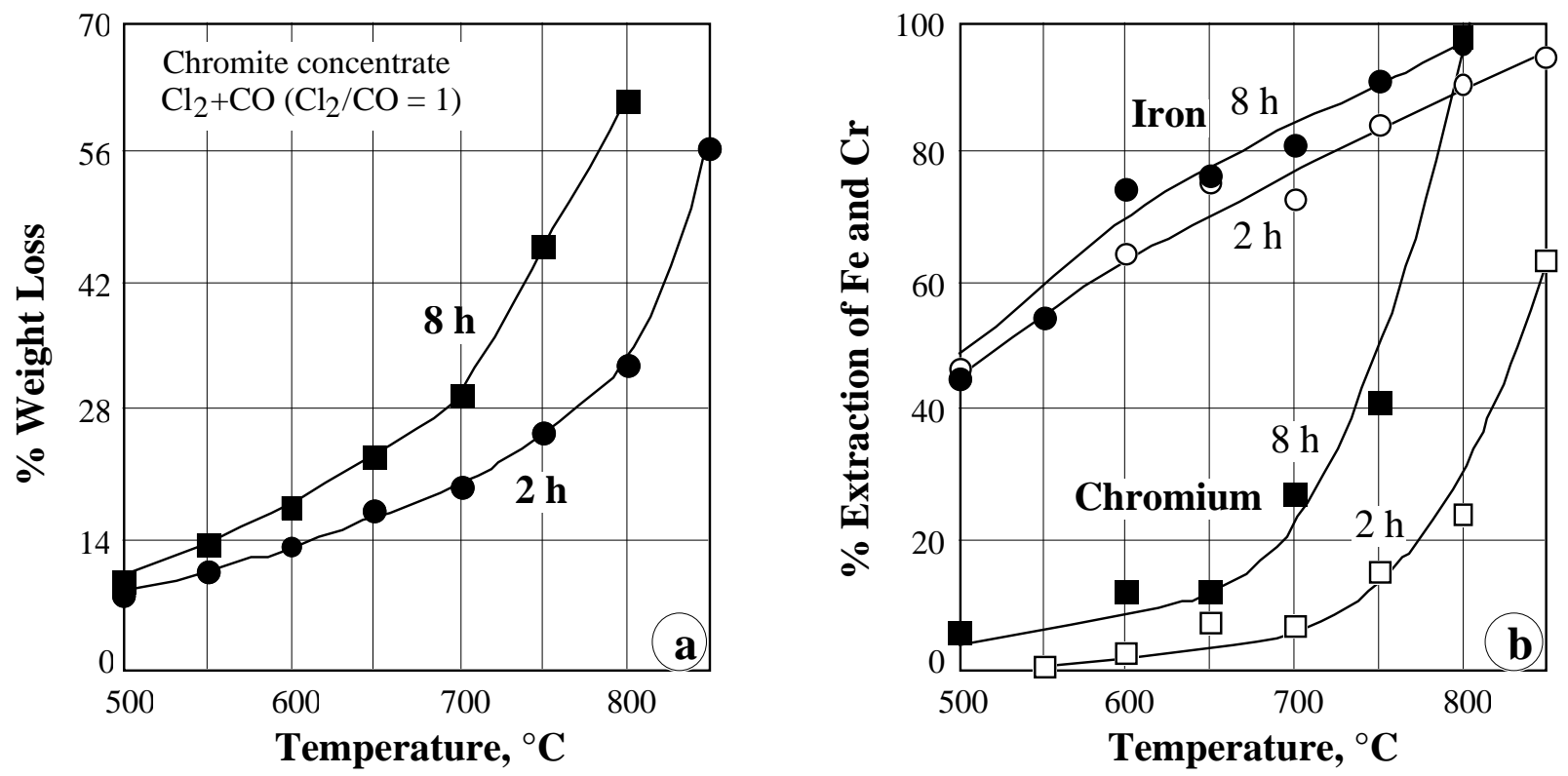

Figure 8 : Evolution of pct WL $(a)$ and extraction of $\mathrm{Cr}$ and $\mathrm{Fe}(b)$ as a function of temperature and reaction time during carbochlorination of chromite.

$\mathbf{T},{ }^{\circ} \mathbf{C}$
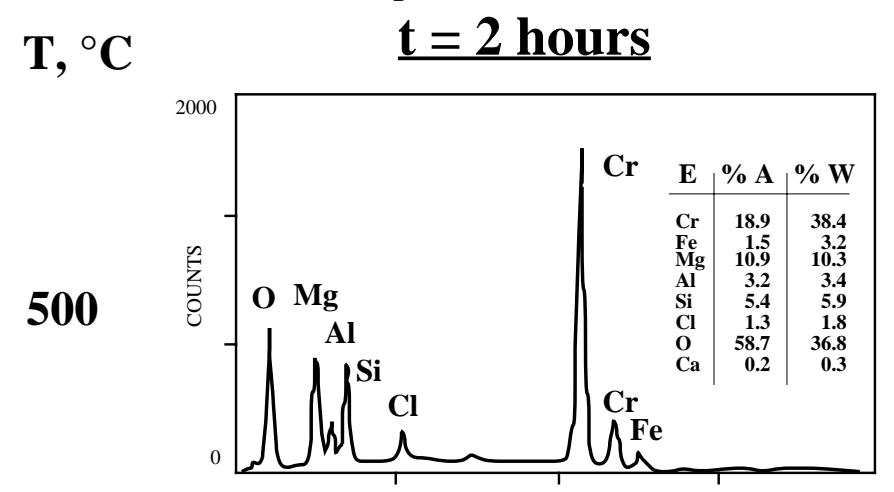

600

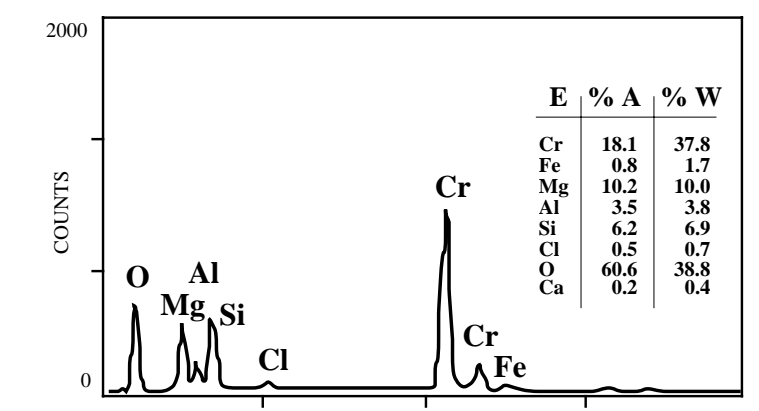

800

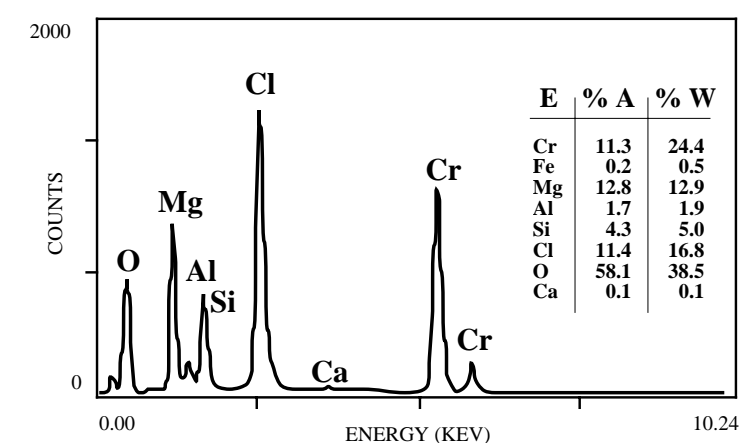

$\underline{t=8 \text { hours }}$
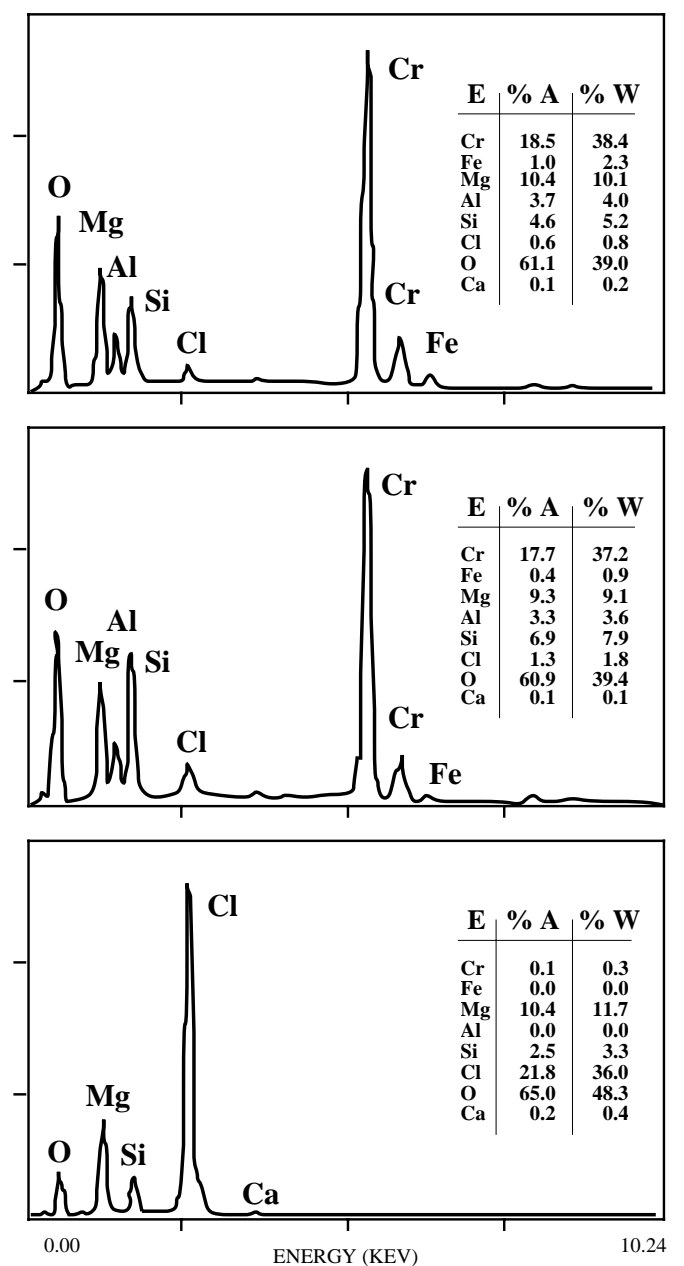

E : Element, \% A : Atomic pct, \% W : Weight pct.

Figure 9 : Semi-quantitative analyses of the carbochlorination residues of chromite concentrate at different temperatures for a reaction time of 2 and 8 hours 


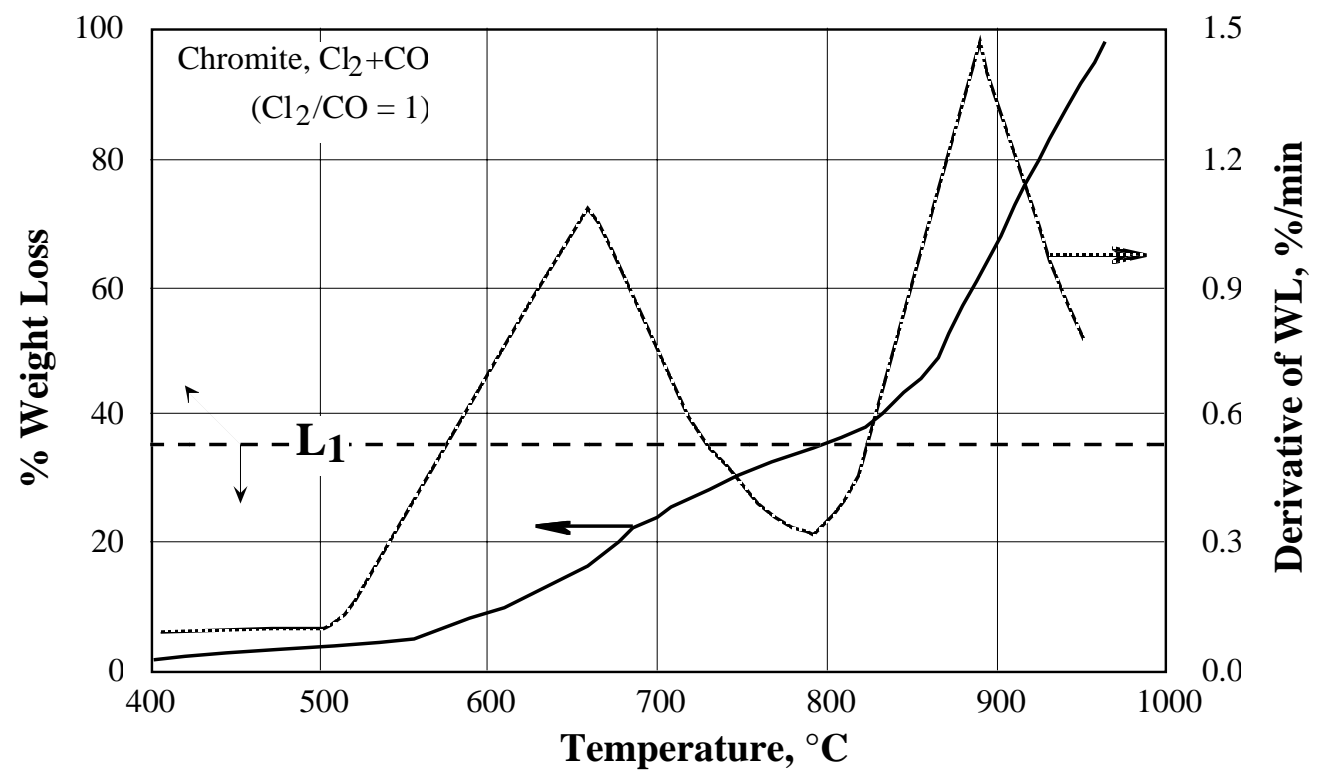

$\mathrm{L}_{1}$ : Weight loss calculated for the carbochlorination of $\left(\mathrm{FeCr}_{2} \mathrm{O}_{4}+\mathrm{Fe}_{3} \mathrm{O}_{4}\right)$

Figure 10 : Evolution of pct WL of the sample and derivative of WL versus temperature during non isothermal carbochlorination of chromite.

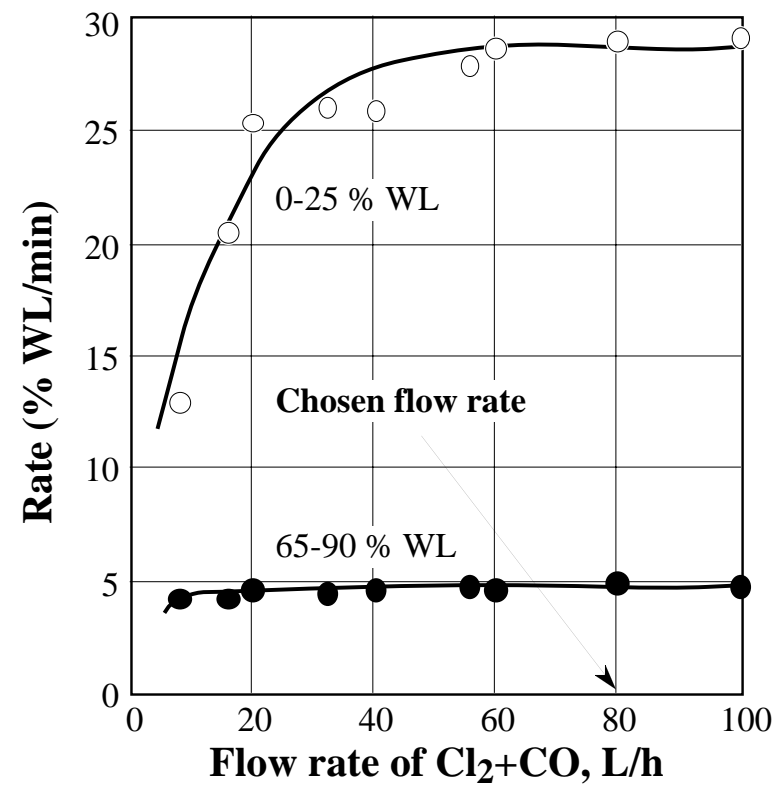

Figure 11 : Effect of gas flow rate on the carbochlorination of chromite at $1000{ }^{\circ} \mathrm{C}$. 

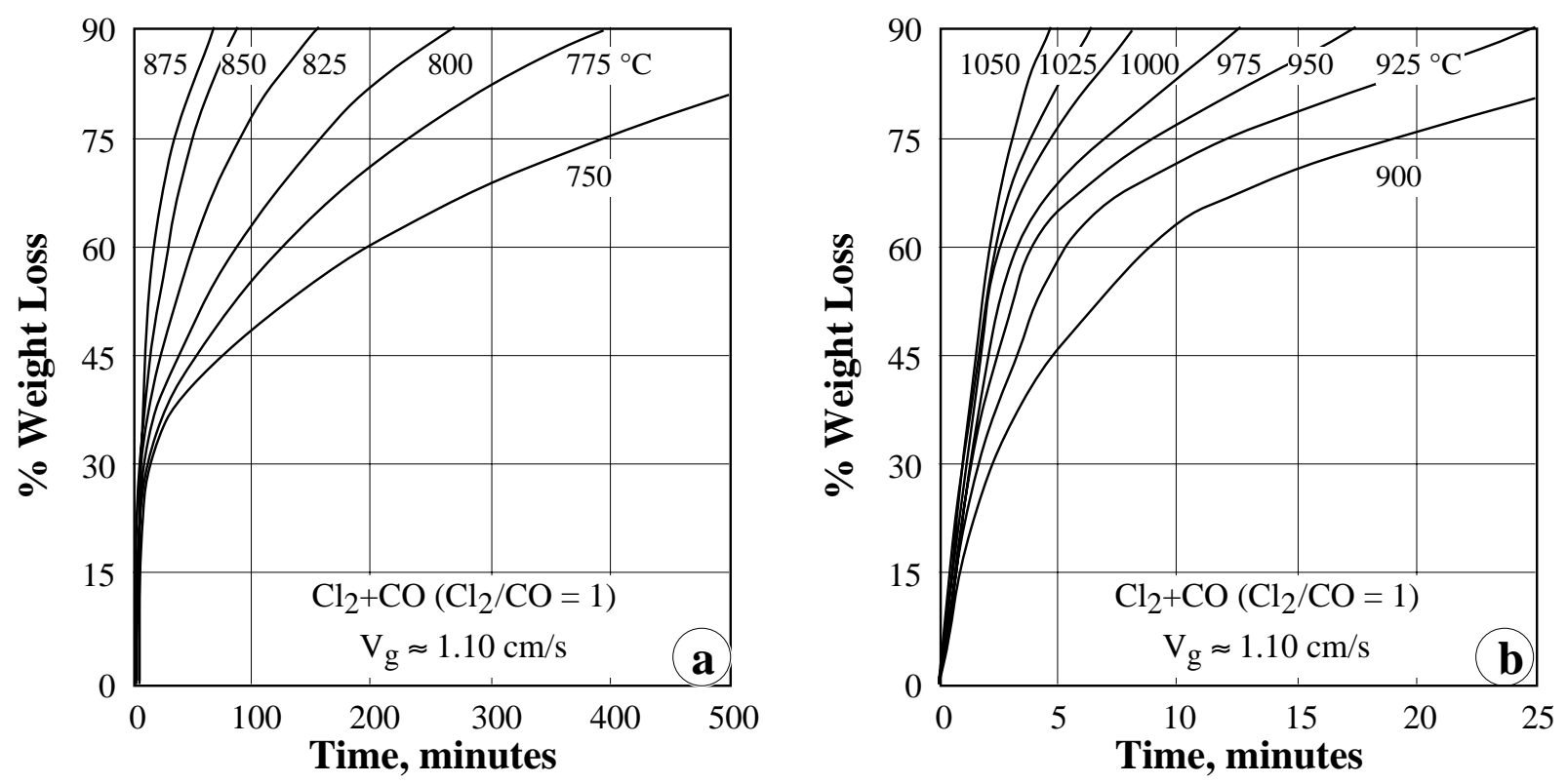

Figure 12 : Isotherms of carbochlorination of chromite from (a) $750{ }^{\circ} \mathrm{C}$ to $875^{\circ} \mathrm{C}$ and (b) $900{ }^{\circ} \mathrm{C}$ to $1050{ }^{\circ} \mathrm{C}$
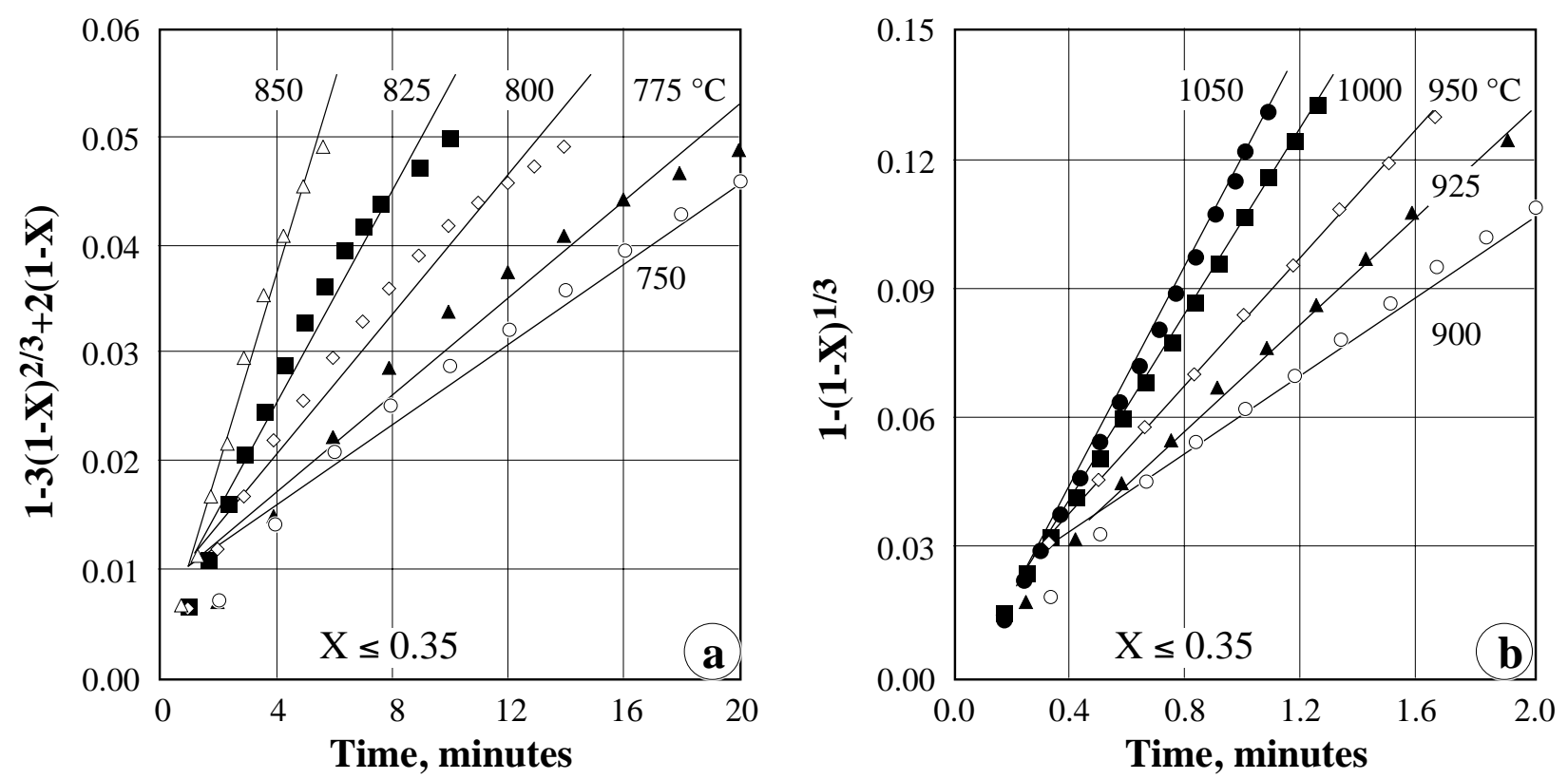

Figure 13 : Mathematical fitting of the carbochlorination data $(X \leq 0.35)$ using Eqs. [17 and 18]. 

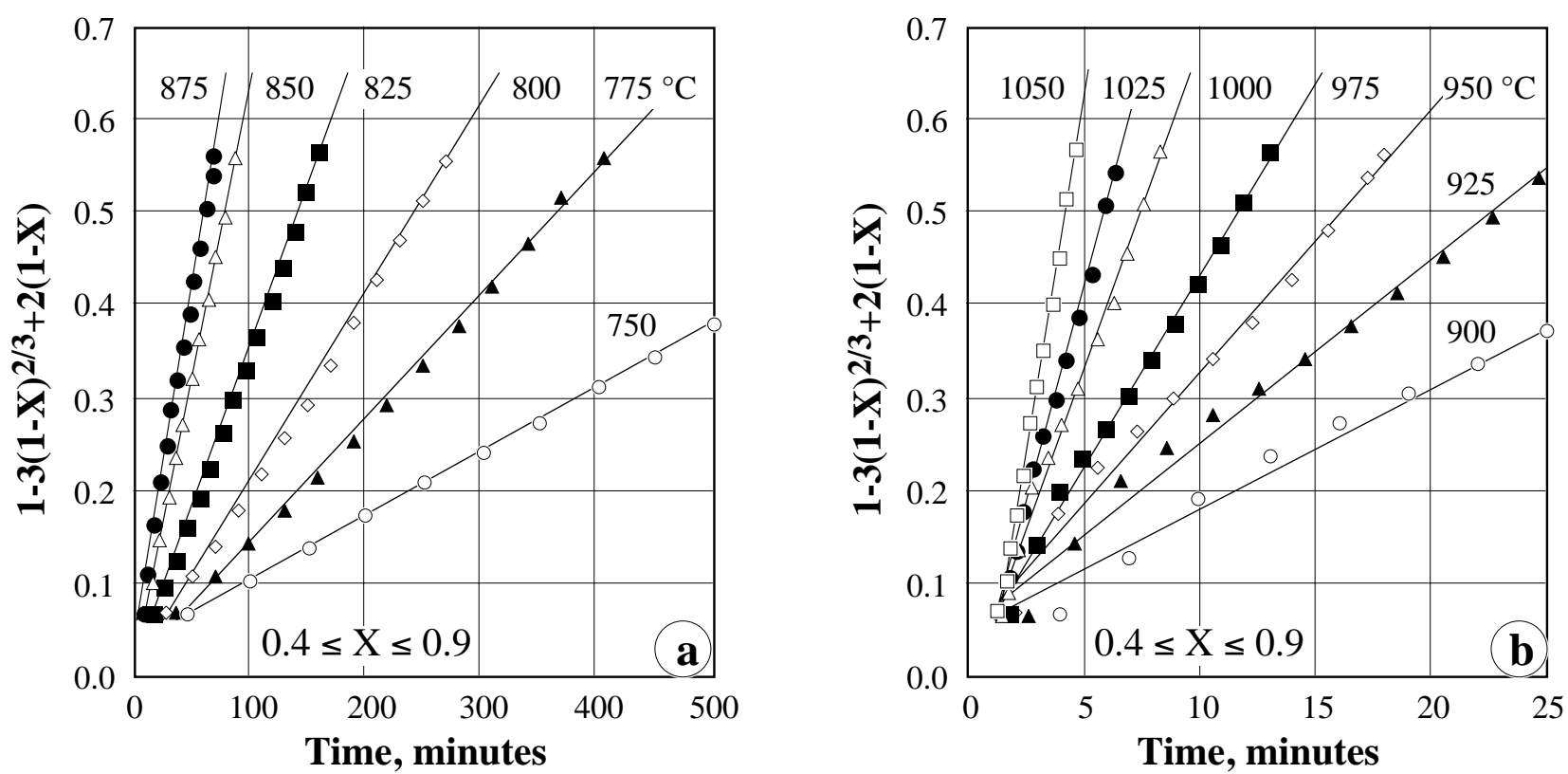

Figure 14 : Mathematical fitting of the carbochlorination data $(0.4 \leq X \leq 0.9)$ using Eq. [17].

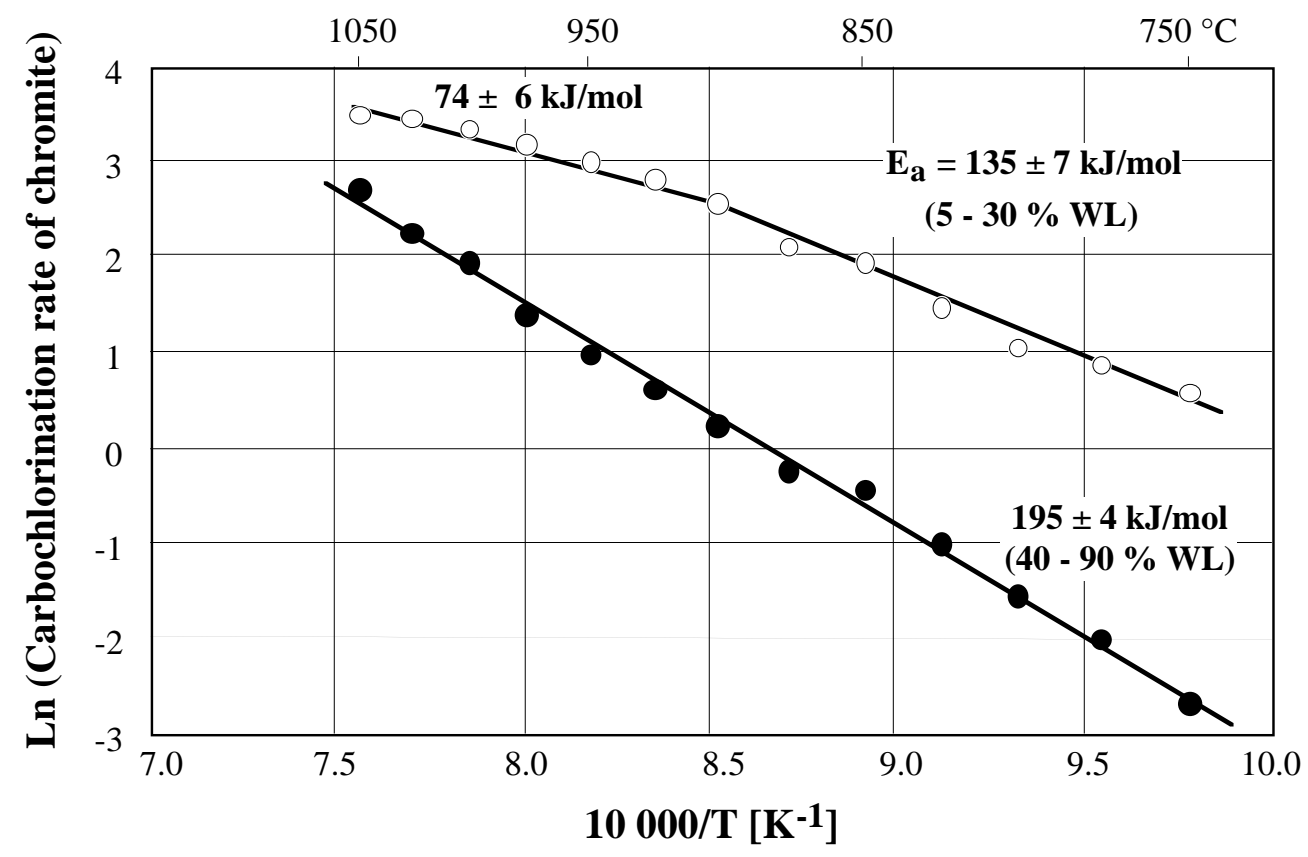

Figure 15 : Arrhenius diagrams of the chromite carbochlorination. 

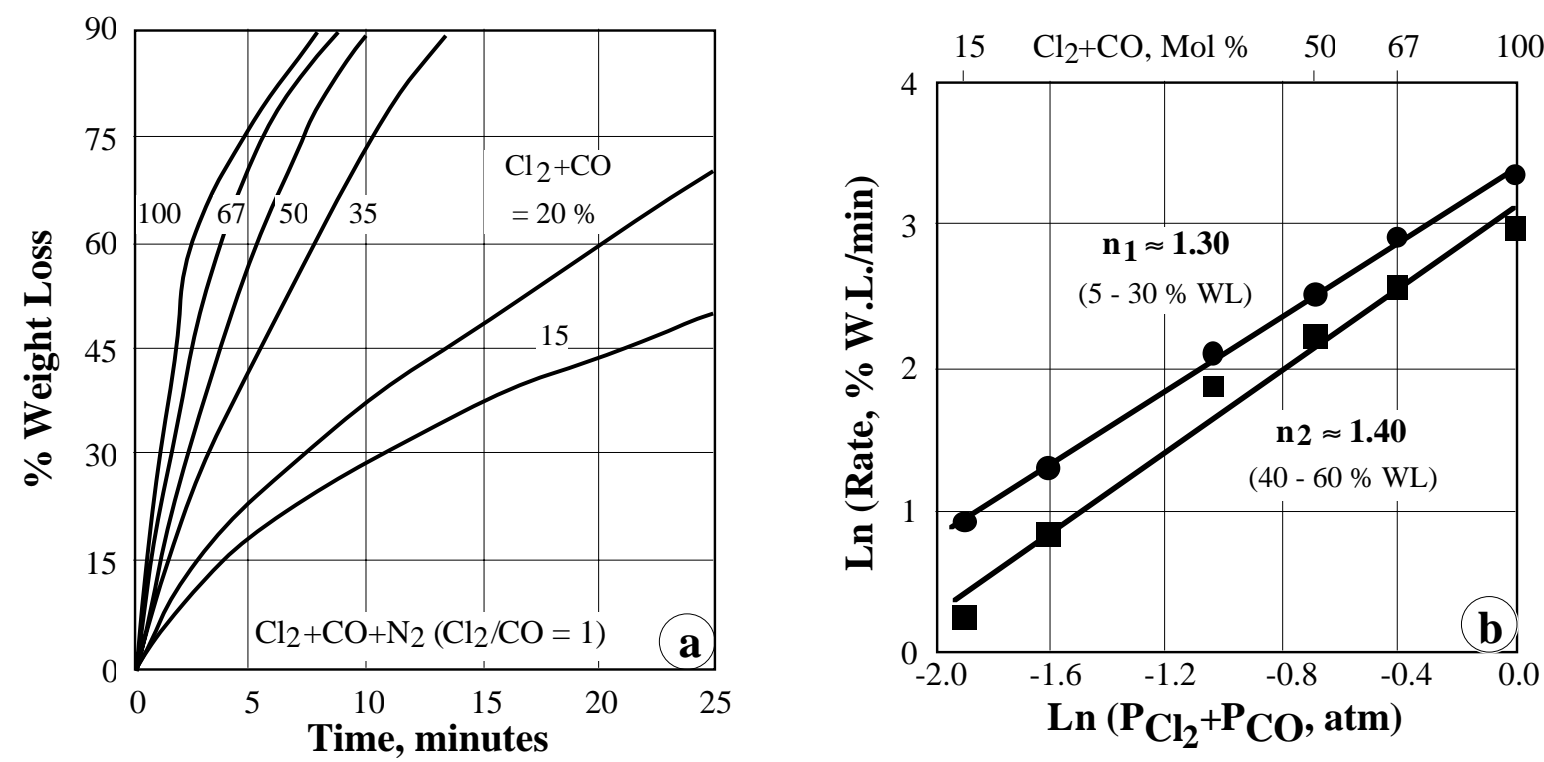

Figure 16 : Isotherms of carbochlorination of chromite at $1000{ }^{\circ} \mathrm{C}(a)$ using various $\mathrm{Cl}_{2}+\mathrm{CO}$ contents and $(b)$ apparent reaction orders with respect to $\mathrm{Cl}_{2}+\mathrm{CO}$. 

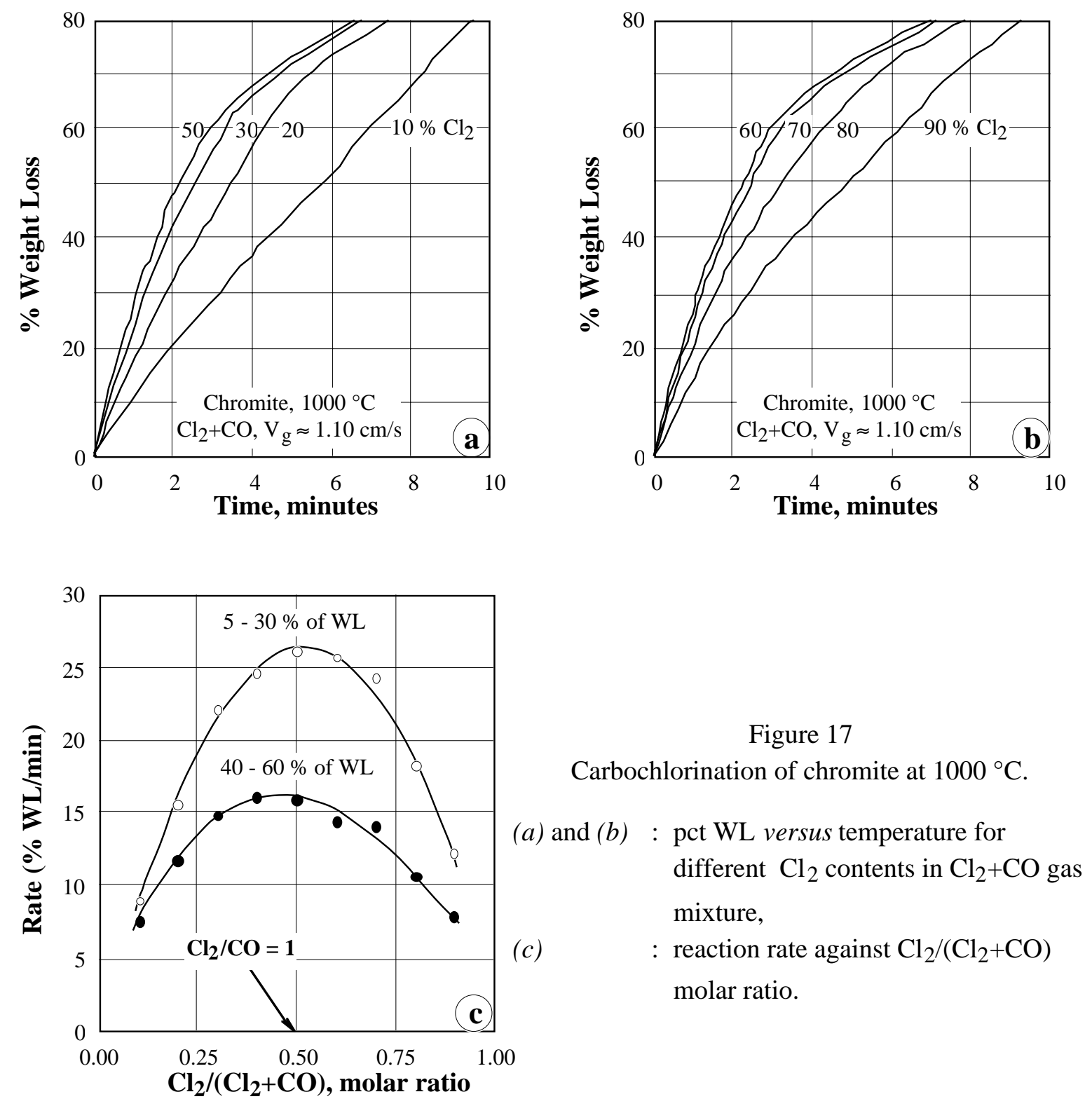